\title{
Reservoir quality of fluvial sandstone reservoirs in salt-walled mini- basins: an example from the Seagull field, Central Graben, North Sea, UK
}

\author{
Stephan Stricker ${ }^{1} \cdot$ Stuart J. Jones ${ }^{1} \cdot$ Neil Meadows $^{2} \cdot$ Leon Bowen $^{3}$
}

Received: 25 July 2017 / Published online: 4 January 2018

(c) The Author(s) 2017. This article is an open access publication

\begin{abstract}
The Triassic fluvial sandstones of the Skagerrak Formation were deposited in a series of salt-walled mini-basins and act as important hydrocarbon reservoirs for several high-pressure, high-temperature (HPHT) fields in the Central Graben, North Sea. The HPHT reservoirs exhibit excellent reservoir quality considering their depth of burial and hence have been of high interest for hydrocarbon exploration. This research uses a multidisciplinary approach to assess the Skagerrak Formation fluvial reservoir quality from the Seagull field incorporating core analysis, petrography, electron microscopy, XRD analysis, fluid inclusion appraisal and burial history modelling. Halokinesis and salt withdrawal at the margin of the saltwalled mini-basin induced early disaggregation bands and fractures at shallow burial and led to increased influx of meteoric water and clay mineral infiltration from overlying sedimentation. The density of disaggregation bands correlates with the occurrence and magnitude of pore-filling authigenic clay minerals, concentrated along the margin of the saltwalled mini-basin. The fluvial channel sandstones of the Skagerrak Formation are subject to strong intra-basinal spatial reservoir quality variations despite diagenesis and low vertical effective stress having played a favourable role in arresting porosity loss.
\end{abstract}

Keywords Reservoir quality · Halokinesis - Diagenesis · Clay minerals · Porosity · Disaggregation bands . Salt-walled mini-basin

\section{Introduction}

The eventual quality of clastic reservoirs, such as grain size, sorting and composition, is initially determined by the environment of deposition. Depositional settings and their effects on reservoir quality are of particular interest for clastic reservoirs, where contemporaneous salt movement influences sedimentation and the resulting distribution of Stephan Stricker
stephan.stricker@durham.ac.uk

Stuart J. Jones

stuart.jones@durham.ac.uk

Neil Meadows

neil@redrock-associates.com

Leon Bowen

leon.bowen@durham.ac.uk

1 Department of Earth Sciences, Durham University, South Road, Durham DH1 3LE, UK

2 RedRock Associates International Limited, 38 Queens Drive, Prenton, Wirral CH43 0RP, UK

3 Department of Physics, Durham University, South Road, Durham DH1 3LE, UK facies (e.g. Fox 1998; Banham and Mountney 2013a, b). Subsequently, burial-related diagenesis also plays a significant role for governing reservoir quality, as it can destroy, preserve or enhance porosity and permeability, depending on diagenetic pathways.

Recent research has contributed to a deeper understanding of salt tectonics and related processes in saltwalled mini-basins (e.g. Hudec and Jackson 2007; Archer et al. 2012; Hudec et al. 2013; Sathar and Jones 2016). Such studies have increased our understanding of salt movement, the development of salt-walled mini-basins and on the effects of coeval halokinesis on sedimentary 
processes and facies distribution (e.g. Fox 1998; Hudec et al. 2009; Banham and Mountney 2013a, b). However, a detailed understanding of the effects of contemporaneous salt movement on diagenesis and reservoir quality is yet to be established.

The Skagerrak Formation was deposited in an array of salt-walled mini-basins within the Central Graben, Central North Sea (e.g. Smith et al. 1993; Bishop 1996; Helgeson 1999; McKie 2014) and is an important reservoir for several high-pressure, high-temperature (HPHT; > $65 \mathrm{MPa}$ and $>150{ }^{\circ} \mathrm{C}$ ) hydrocarbon accumulations. This study utilized channel sandstone samples of the Judy Sandstone Member of the Skagerrak Formation from the wells 22/292 and 22/29-3 (Seagull field) to identify:

- How the salt-walled mini-basin setting controls reservoir quality in the fluvial sandstones of Triassic Skagerrak Formation, Central North Sea, UK and:

- How contemporaneous salt movement influences fracturing, clay infiltration and diagenesis to guide prediction of best reservoir quality in salt-walled mini-basins.

\section{Geological setting}

\subsection{Central Graben of the North Sea}

The Central Graben of the North Sea is a prolific hydrocarbon province of $70-130 \mathrm{~km}$ width and $550 \mathrm{~km}$ length. It forms the southern arm of a trilete rift system (i.e. an incipient ridge-ridge triple junction) in the North Sea with the Viking Graben (VG) as the northern arm and the Moray Firth Basin (MFB) as the western arm (Fig. 1a) (di Primio and Neumann 2008). The Forties-Montrose High and Josephine Ridge horst blocks divide the Central Graben into the East Central Graben (ECG) and the West Central Graben (WCG), flanked by the Norwegian basement in the east and the UK continental shelf in the west. The rift system developed in at least two major extension phases, one during the Permian-Triassic (290-210 Ma) and another in the Late Jurassic (155-140 Ma) (Gowers et al. 1985; Taylor 1998).

This study focuses on the 22/29-2 and 22/29-3 wells of the Seagull field located at the southern end of the FortiesMontrose High in UK Quadrant 22 (Fig. 1b). The 22/29-2 well is located in a salt-walled mini-basin centre (Fig. 2a, b), whereas 22/29-3 is located more proximal to a salt wall.

\subsection{Skagerrak Formation stratigraphy}

The Triassic strata of the Central North Sea area have been previously described in some detail, (e.g. Goldsmith et al. 2003; McKie and Audretsch 2005; McKie 2014) (Fig. 3).
This thick succession of entirely continental strata is subdivided into the Early Triassic Smith Bank and Bunter Formations (shales, evaporites and thin sands) and the Middle to Late Triassic Skagerrak Formation (thickly interbedded sands and shales). The Middle to Late Triassic Skagerrak Formation in the Central Graben, North Sea, comprises 500-1000 m (1640-3280 ft) of predominantly continental braided and meandering fluvial system deposits and terminal fluvial fan deposits with lacustrine facies (McKie and Audretsch 2005; De Jong et al. 2006; Kape et al. 2010; Stricker et al. 2016b). The stratigraphic nomenclature of the Triassic for the Central Graben was defined by Goldsmith et al. (1995), based on detailed biostratigraphic and lithostratigraphic correlation of wells from the Josephine Ridge and was extended and correlated towards the study area (Fig. 1b) by McKie and Audretsch (2005).

The Skagerrak Formation in the Central Graben is subdivided into three sand-dominated members (Judy, Joanne and Josephine) and three mud-dominated members (Julius, Jonathan and Joshua) (Fig. 3). The sand-dominated members include sheetflood deposits and multi-story stacked channel sandbodies (Goldsmith et al. 1995; McKie and Audretsch 2005), whereas the mud-dominated members include a variation of non-marine, basin-wide floodplain and playa lake deposits. The thick and laterally extensive mud-dominated units provide the main correlative units for the Skagerrak Formation in the Central Graben (McKie and Audretsch 2005). The present-day Triassic stratigraphy of the study area is incomplete due to deep erosion during the Middle and Late Jurassic (Erratt et al. 1999; McKie et al. 2010). The stratigraphy comprises the Early Triassic Smith Bank and Bunter Formations and the lowermost members of the Skagerrak Formation (Judy Member and Julius Member) (McKie and Audretsch 2005; McKie et al. 2010).

The Skagerrak Formation of the Seagull field comprises a major sandstone reservoir, the Judy Sandstone Member, which is bound by the regional shale markers, the Marnock and Heron Shales, equivalent to the Julius Mudstone Member and the upper Smith Bank (Fig. 3). McKie and Audretsch (2005) subdivided the Judy Member into a lower terminal splay-dominated interval and an upper channelized interval, separated by a shale-prone section. The lower terminal splay facies is characterized by fine-grained, planar cross-bedded and ripple-laminated sandstones. In comparison, the upper interval is dominated by channel-fill deposits, which are organized into fining upward packages with coarse lag deposits (usually with ripped-up calcrete nodules) commonly occurring at the base. Channel-fill deposits are characterized by well-sorted cross-bedded sandstones and can be separated into channel and sheet- 


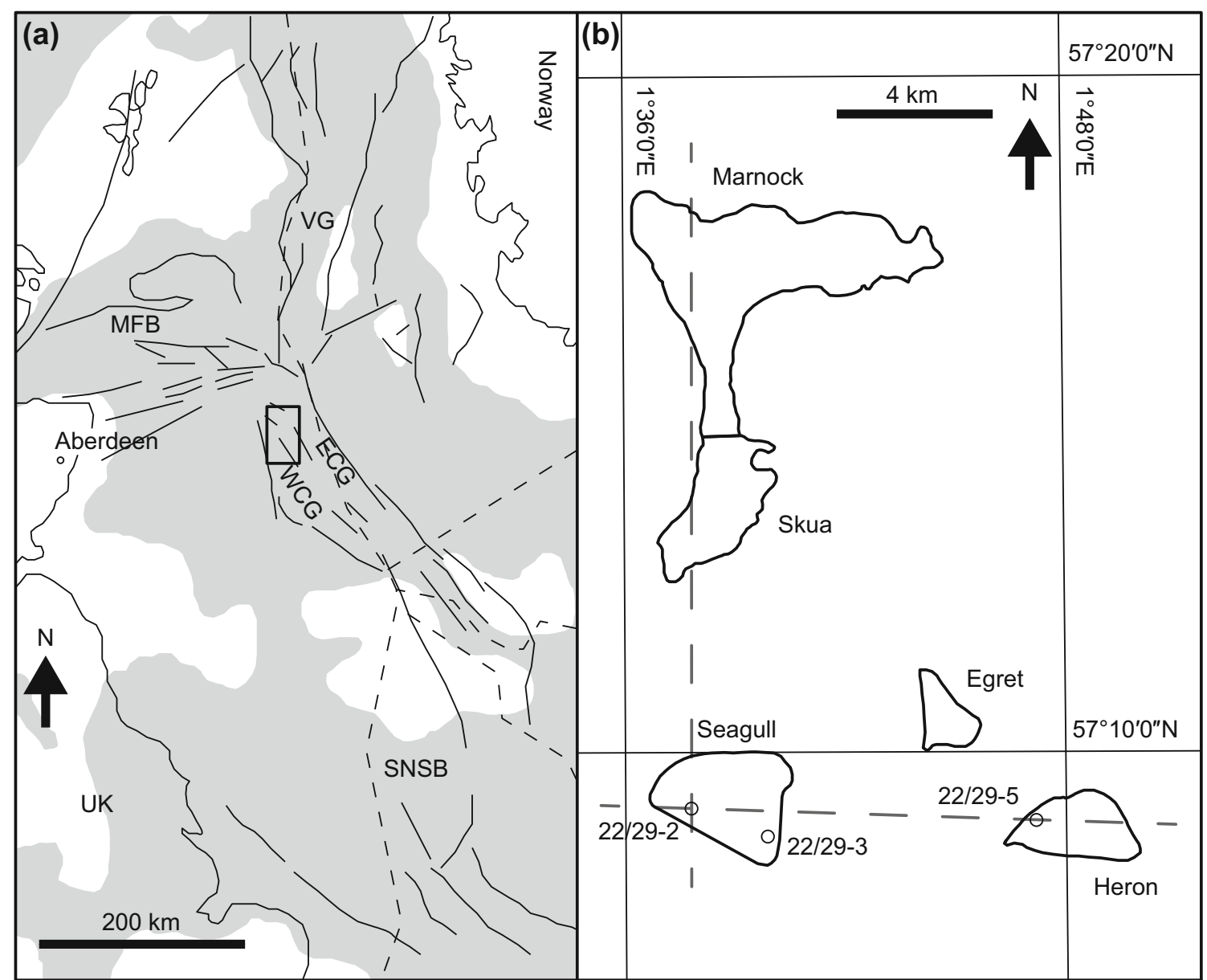

Fig. 1 Central North Sea location with a Regional distribution of the Triassic basin-fill in the North Sea region (grey) after Mckie et al. (2010) and McKie and Shannon (2011) and major structural features, with $V G$ Viking Graben, $M F B$ Moray Firth Basin, ECG East Central Graben, $W C G$ West Central Graben and SNSB Southern North Sea

dominated sandstones (McKie and Audretsch 2005; McKie 2011).

\subsection{Mini-basin development and halokinesis}

Triassic sediments of the Central Graben accumulated directly on top of the Late Permian Zechstein salt within a series of fault-controlled and salt-controlled mini-basins (Figs. 2, 4). The Late Permian Zechstein salt strongly controlled the Triassic deposition by forming salt withdrawal mini-basins within an overall rift-controlled basinal tectonic setting (Smith et al. 1993; Bishop 1996; Matthews et al. 2007). The initiation of mini-basin subsidence or creation of salt-walled mini-basins requires the presence of salt with a sufficient thickness to allow halokinesis (Hudec et al. 2009), and a mechanism to initiate halokinesis, i.e. extension, compression, differential loading or buoyancy (Banham and Mountney 2013a). The halokinesis of the Zechstein evaporites started during the Early Triassic and
Basin after Brown (1991); b Detailed outline of the study area (in black box on the regional map) with the hydrocarbon reservoirs of the area (Egret, Heron, Marnock, Seagull and Skua) and location of the schematic cross sections (Fig. 2) (dashed lines)

has been associated with rifting in response to the Hardegsen tectonic event (McKie 2014). Reactivation of the Permian fault system and localized loading by ongoing Triassic sedimentation together with uneven salt distribution resulted in a complex topography (Hodgson et al. 1992; Smith et al. 1993; Bishop 1996; Matthews et al. 2007). This led to variations in the mini-basin development and the creation of accommodation space throughout the Triassic period, together with the potential for mini-basin grounding (Fig. 2a). The coeval halokinesis of the Zechstein salt significantly influenced the depositional environment of the Triassic sediments in the Central Graben. Coeval halokinesis controlled the overall subsidence of the mini-basins, sediment transport pathways and the reworking of uplifted sediments (e.g. Banham and Mountney 2013b). Salt withdrawal and reduced salt thickness below the Seagull mini-basin allowed grounding in the Early to Middle Triassic on the underlying Rotliegend basement (Fig. 2a, b) (McKie and Audretsch 2005; McKie et al. 


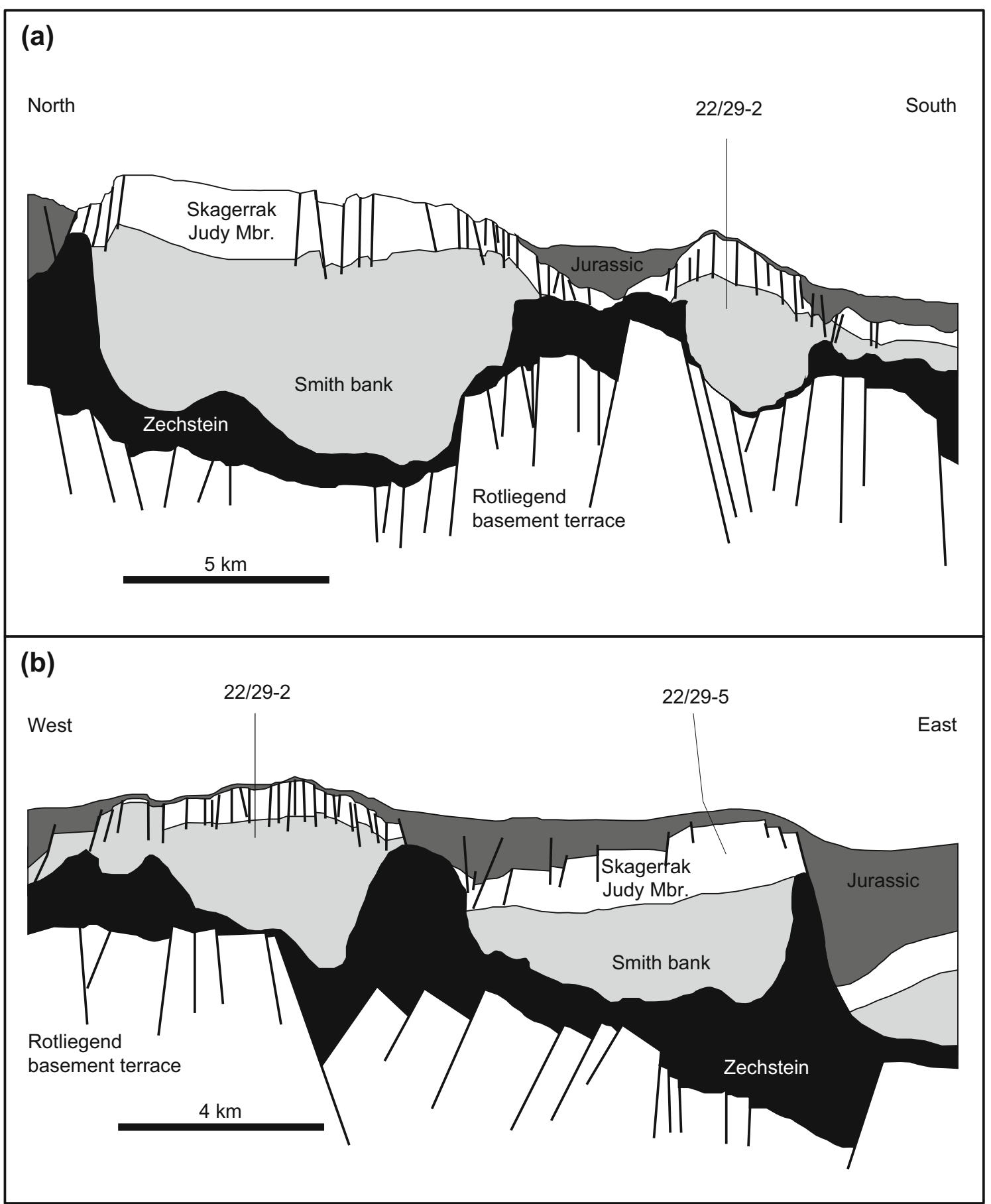

Fig. 2 Schematic cross sections of $\mathbf{a}$ north-south and $\mathbf{b}$ east-west direction highlighting the mini-basin structure and location of salt walls, with the location of the 22/29-2 (Seagull) and 22/29-5 (Heron) well after McKie et al. (2010) and McKie (2011)

2010). The syn-rift and halokinesis controlled Smith Bank Formation sediments representing the bulk and basal part of the mini-basin infill, whereas the overlying post-rift and halokinesis controlled Skagerrak Formation sediments are the thinner upper part of the mini-basin infill. Coeval halokinesis and varying Zechstein salt thickness created variable accommodation space for the Early and Middle
Triassic sediments within mini-basins and between different mini-basins (Fig. 2) that has influenced reservoir thickness and diagenesis, e.g. halite cements related to the Zechstein salt mobilization (Nguyen et al. 2013). 


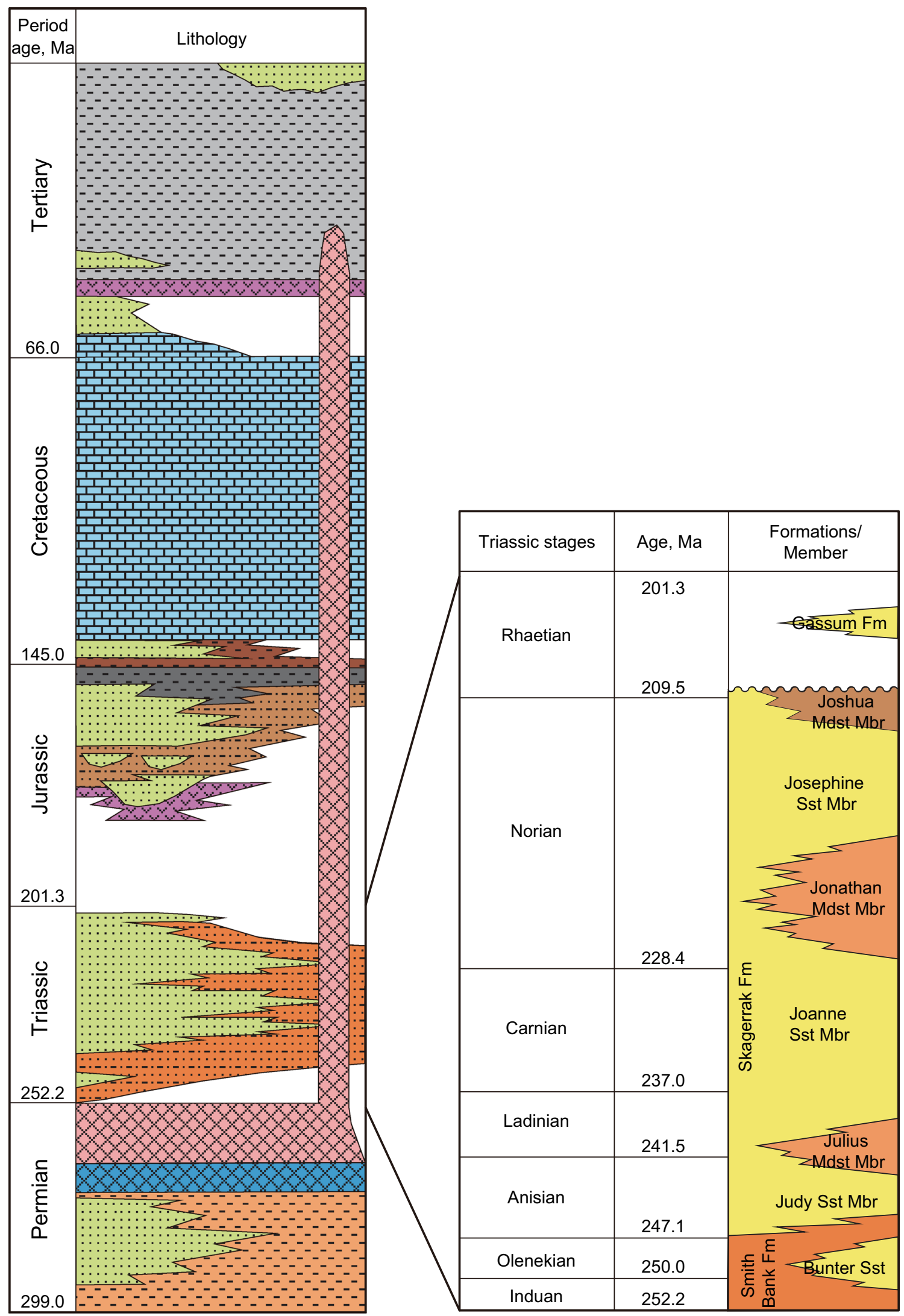

Fig. 3 General Central North Sea stratigraphy after Evans et al. (2003), McKie and Williams (2009) and McKie (2014), geological ages after Gradstein et al. (2012) 


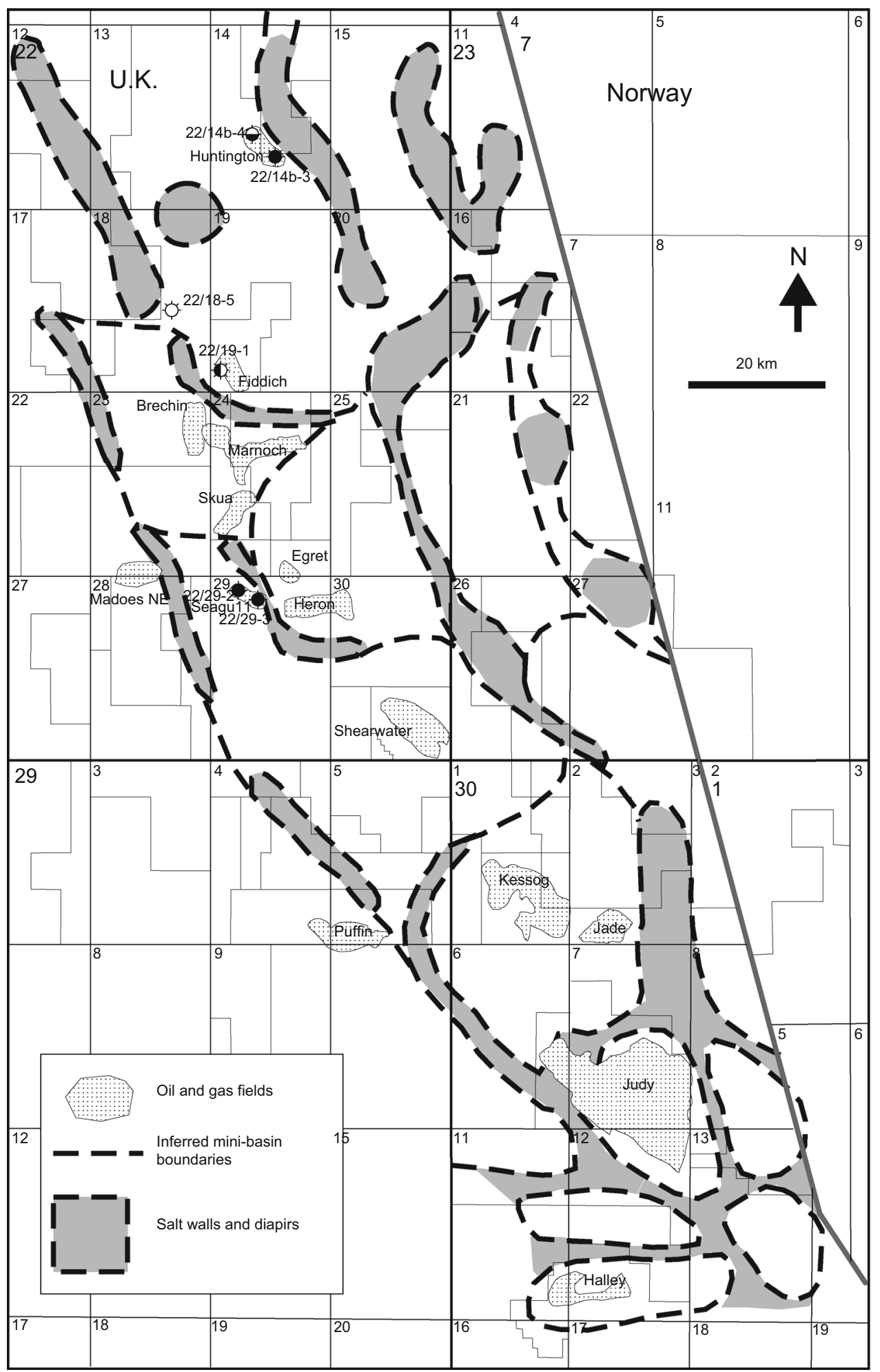

Fig. 4 Salt wall and mini-basin map of the wider Central Graben area (Quadrant 22, 23, 29, 30), showing the location of major salt walls, diapirs and salt-walled mini-basins 
$22 / 29-2 \quad 22 / 29-3$

Porosity, \%

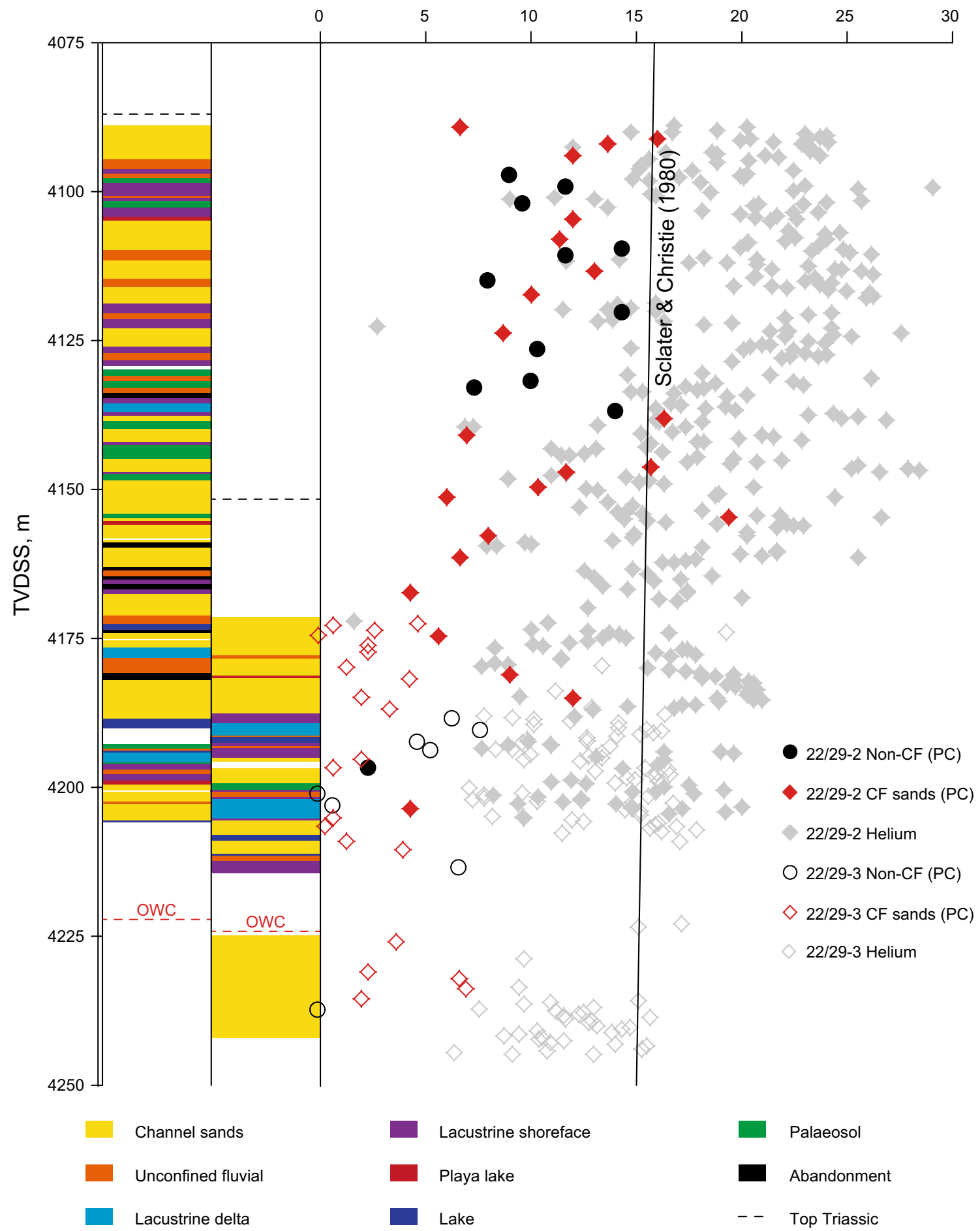

Fig. 5 Facies interpretation of the 22/29-2 and 22/29-3 core material, with the porosity distribution (point count) of the channel sandstone samples [CF sands (PC)], non-channel sandstone samples [Non-CF (PC)] and helium porosity from core plugs of the 22/29-2 well (solid)

and the 22/29-3 well (hollow), and a regional Central North Sea porosity-depth relationship for shaly sandstone by Sclater and Christie (1980) 
Table 1 Petrographic and point count data for the 22/29-2 sample set, with sample depth in metre and feet TVDSS, facies type [channel sand (CF), unconfined fluvial (UCF), lacustrine shoreface (LSF)], grain size (GS), coated grains with $>80 \%$ coated surface $(\mathrm{CG})$, and point count values for detrital quartz grains (Qtz), detrital feldspar grains (Feld), lithic fragments (Lith), mica (Mica), clay mineral cements $(\mathrm{CM})$, carbonate cements $(\mathrm{Carb})$ and porosity $\left(P_{\mathrm{PC}}\right)$

\begin{tabular}{|c|c|c|c|c|c|c|c|c|c|c|c|}
\hline \multicolumn{2}{|l|}{ Depth } & \multirow[b]{2}{*}{ Facies, $[-]$} & \multirow[b]{2}{*}{$\mathrm{GS}, \mathrm{mm}$} & \multirow[b]{2}{*}{$\mathrm{CG}, \%$} & \multicolumn{7}{|c|}{ Point count (300) } \\
\hline TVDSS, m & TVDSS, ft & & & & Qtz, \% & Feld, \% & Lith, \% & Mica, \% & $\mathrm{CM}, \%$ & Carb, \% & $P_{\mathrm{PC}}, \%$ \\
\hline 4089.15 & $13,415.83$ & $\mathrm{CF}$ & 0.148 & 86.6 & 54.7 & 13.3 & 3.7 & 3.3 & 18.3 & 0.0 & 6.7 \\
\hline 4091.23 & $13,422.66$ & $\mathrm{CF}$ & 0.210 & 75.6 & 49.0 & 10.3 & 3.7 & 2.0 & 19.0 & 0.0 & 16.0 \\
\hline 4092.04 & $13,425.33$ & $\mathrm{CF}$ & 0.298 & 85.3 & 56.7 & 10.3 & 2.3 & 1.3 & 15.7 & 0.0 & 13.7 \\
\hline 4094.07 & $13,432.00$ & $\mathrm{CF}$ & 0.272 & 84.3 & 51.0 & 12.7 & 2.0 & 2.0 & 20.3 & 0.0 & 12.0 \\
\hline 4097.45 & $13,443.08$ & $\mathrm{UCF}$ & 0.192 & 72.6 & 48.0 & 22.7 & 4.0 & 1.7 & 11.3 & 3.3 & 9.0 \\
\hline 4099.36 & $13,449.33$ & LSF & 0.162 & 94.3 & 43.7 & 17.7 & 1.3 & 1.3 & 24.3 & 0.0 & 11.7 \\
\hline 4102.07 & $13,458.25$ & LSF & 0.124 & 89.3 & 38.7 & 22.3 & 2.0 & 8.0 & 18.7 & 0.7 & 9.7 \\
\hline 4104.74 & $13,467.00$ & $\mathrm{CF}$ & 0.166 & 79.3 & 42.7 & 15.3 & 6.0 & 3.0 & 21.0 & 0.0 & 12.0 \\
\hline 4108.14 & $13,478.16$ & $\mathrm{CF}$ & 0.183 & 67.6 & 46.7 & 13.3 & 8.0 & 2.3 & 18.0 & 0.3 & 11.3 \\
\hline 4109.72 & $13,483.33$ & $\mathrm{UCF}$ & 0.165 & 85.0 & 44.7 & 14.0 & 4.0 & 1.0 & 21.7 & 0.3 & 14.3 \\
\hline 4111.07 & $13,487.75$ & $\mathrm{UCF}$ & 0.158 & 74.0 & 43.7 & 12.7 & 6.3 & 3.0 & 22.3 & 0.3 & 11.7 \\
\hline 4113.53 & $13,495.83$ & $\mathrm{CF}$ & 0.194 & 83.3 & 49.3 & 18.7 & 4.0 & 0.3 & 14.7 & 0.0 & 13.0 \\
\hline 4115.23 & $13,501.41$ & $\mathrm{UCF}$ & 0.113 & 88.0 & 35.7 & 18.0 & 2.0 & 6.0 & 30.3 & 0.0 & 8.0 \\
\hline 4117.31 & $13,508.25$ & $\mathrm{CF}$ & 0.104 & 91.6 & 48.3 & 10.0 & 4.0 & 3.7 & 24.0 & 0.0 & 10.0 \\
\hline 4120.59 & $13,519.00$ & UCF & 0.179 & 78.6 & 54.3 & 17.0 & 4.0 & 1.0 & 9.3 & 0.0 & 14.3 \\
\hline 4123.71 & $13,529.25$ & $\mathrm{CF}$ & 0.188 & 66.3 & 52.3 & 16.7 & 7.0 & 4.0 & 11.3 & 0.0 & 8.7 \\
\hline 4126.66 & $13,538.91$ & LSF & 0.190 & 98.3 & 45.0 & 21.0 & 4.7 & 2.0 & 16.7 & 0.3 & 10.3 \\
\hline 4132.12 & $13,556.83$ & $\mathrm{UCF}$ & 0.121 & 87.0 & 45.0 & 8.3 & 3.0 & 5.3 & 27.0 & 1.3 & 10.0 \\
\hline 4133.24 & $13,560.50$ & $\mathrm{UCF}$ & 0.271 & 63.0 & 60.7 & 13.0 & 6.7 & 0.3 & 11.3 & 0.7 & 7.3 \\
\hline 4137.10 & $13,573.16$ & LSF & 0.166 & 62.6 & 45.3 & 21.0 & 2.0 & 2.7 & 15.0 & 0.0 & 14.0 \\
\hline 4138.29 & $13,577.08$ & $\mathrm{CF}$ & 0.239 & 96.0 & 45.7 & 16.0 & 7.7 & 0.3 & 14.0 & 0.0 & 16.3 \\
\hline 4140.88 & $13,585.58$ & $\mathrm{CF}$ & 0.129 & 98.6 & 39.3 & 14.7 & 2.7 & 5.7 & 30.3 & 0.3 & 7.0 \\
\hline 4141.49 & $13,587.58$ & $\mathrm{CF}$ & 0.198 & 27.3 & & & & & & & \\
\hline 4146.35 & $13,603.50$ & $\mathrm{CF}$ & 0.168 & 58.6 & 48.0 & 17.0 & 4.7 & 0.7 & 13.7 & 0.3 & 15.7 \\
\hline 4147.11 & $13,606.00$ & $\mathrm{CF}$ & 0.154 & 43.6 & 47.3 & 19.0 & 5.0 & 0.7 & 16.3 & 0.0 & 11.7 \\
\hline 4149.77 & $13,614.75$ & $\mathrm{CF}$ & 0.124 & 22.3 & 40.7 & 22.0 & 3.0 & 4.0 & 20.0 & 0.0 & 10.3 \\
\hline 4151.48 & $13,620.33$ & $\mathrm{CF}$ & 0.189 & 50.0 & 47.0 & 13.0 & 8.7 & 1.3 & 24.0 & 0.0 & 6.0 \\
\hline 4154.70 & $13,630.91$ & $\mathrm{CF}$ & 0.216 & 98.0 & 46.3 & 13.7 & 3.7 & 0.3 & 16.7 & 0.0 & 19.3 \\
\hline 4157.78 & $13,641.00$ & $\mathrm{CF}$ & 0.140 & & 46.0 & 14.3 & 10.0 & 5.7 & 16.0 & 0.0 & 8.0 \\
\hline 4161.38 & $13,652.83$ & $\mathrm{CF}$ & 0.169 & 96.6 & 46.0 & 16.7 & 2.0 & 1.3 & 27.3 & 0.0 & 6.7 \\
\hline 4167.33 & $13,672.33$ & $\mathrm{CF}$ & 0.096 & 65.3 & 40.0 & 15.7 & 1.7 & 3.3 & 33.3 & 1.7 & 4.3 \\
\hline 4174.84 & $13,697.00$ & $\mathrm{CF}$ & 0.231 & 7.6 & 40.3 & 12.7 & 7.0 & 0.0 & 9.0 & 25.3 & 5.7 \\
\hline 4181.30 & $13,718.16$ & $\mathrm{CF}$ & 0.181 & 73.6 & 45.0 & 21.3 & 5.7 & 2.0 & 10.3 & 6.7 & 9.0 \\
\hline 4185.11 & $13,730.66$ & $\mathrm{CF}$ & 0.195 & 41.3 & 47.0 & 16.7 & 5.0 & 0.7 & 17.7 & 1.0 & 12.0 \\
\hline 4196.89 & $13,769.33$ & UCF & 0.100 & 43.6 & 36.1 & 30.7 & 5.4 & 2.0 & 21.3 & 2.0 & 2.4 \\
\hline 4203.57 & $13,791.25$ & $\mathrm{CF}$ & 0.160 & 88.3 & 47.7 & 29.7 & 4.0 & 0.3 & 11.7 & 2.3 & 4.3 \\
\hline
\end{tabular}

\section{Methodology}

\subsection{Sampling}

Core samples and thin sections examined in this study have been selected from channel sandstone facies of the wells
22/29-2 and 22/29-3 (Fig. 5). For the purposes of this study the sedimentary facies of the sandstone members within the Skagerrak Formation broadly follow previous published descriptions of the succession (Goldsmith et al. 1995, 2003; McKie and Audretsch 2005; McKie 2014). These have been modified slightly with regard to seminal papers on the 
Table 2 Petrographic and point count data for the 22/29-3 sample set, with sample depth in metre and feet TVDSS, facies type [channel sand (CF), unconfined fluvial (UCF), lacustrine shoreface (LSF)], grain size (GS), coated grains with $>80 \%$ coated surface $(\mathrm{CG})$, and point count values for detrital quartz grains (Qtz), detrital feldspar grains (Feld), lithic fragments (Lith), mica (Mica), clay mineral cements $(\mathrm{CM})$, carbonate cements $(\mathrm{Carb})$ and porosity $\left(\mathrm{P}_{\mathrm{PC}}\right)$

\begin{tabular}{|c|c|c|c|c|c|c|c|c|c|c|c|}
\hline \multicolumn{2}{|l|}{ Depth } & \multirow[b]{2}{*}{ Facies, $[-]$} & \multirow[b]{2}{*}{$\mathrm{GS}, \mathrm{mm}$} & \multirow[b]{2}{*}{ CG, \% } & \multicolumn{7}{|c|}{ Point count $(300)$} \\
\hline TVDSS, m & TVDSS, ft & & & & Qtz, \% & Feld, \% & Lith, \% & Mica, \% & $\mathrm{CM}, \%$ & Carb, \% & $P_{\mathrm{PC}}, \%$ \\
\hline 4172.71 & $13,690.00$ & $\mathrm{CF}$ & 0.154 & 72.0 & 47.3 & 8.3 & 7.0 & 2.7 & 30.0 & 0.0 & 4.7 \\
\hline 4173.09 & $13,691.25$ & $\mathrm{CF}$ & 0.124 & 76.0 & 50.3 & 10.0 & 7.7 & 2.7 & 28.3 & 0.3 & 0.7 \\
\hline 4173.78 & $13,693.50$ & $\mathrm{CF}$ & 0.134 & 78.3 & 44.0 & 11.7 & 6.3 & 0.7 & 34.7 & 0.0 & 2.7 \\
\hline 4174.64 & $13,696.33$ & $\mathrm{CF}$ & 0.121 & 39.3 & 49.7 & 10.3 & 4.3 & 3.3 & 32.3 & 0.0 & 0.0 \\
\hline 4176.45 & $13,702.25$ & $\mathrm{CF}$ & 0.141 & 61.6 & 44.7 & 9.7 & 5.0 & 2.3 & 35.7 & 0.3 & 2.3 \\
\hline 4177.54 & $13,705.83$ & $\mathrm{CF}$ & 0.143 & 40.6 & 51.7 & 11.0 & 7.0 & 3.0 & 25.0 & 0.0 & 2.3 \\
\hline 4180.18 & $13,714.50$ & $\mathrm{CF}$ & 0.146 & 58.3 & 45.3 & 10.0 & 3.3 & 5.0 & 35.0 & 0.0 & 1.3 \\
\hline 4181.96 & $13,720.33$ & $\mathrm{CF}$ & 0.127 & & 44.7 & 8.3 & 3.0 & 3.7 & 36.0 & 0.0 & 4.3 \\
\hline 4185.06 & $13,730.50$ & $\mathrm{CF}$ & 0.189 & 35.6 & 54.3 & 7.7 & 7.0 & 0.7 & 28.3 & 0.0 & 2.0 \\
\hline 4187.06 & $13,737.08$ & $\mathrm{CF}$ & 0.163 & 54.0 & 55.3 & 6.0 & 6.3 & 2.0 & 27.0 & 0.0 & 3.3 \\
\hline 4188.89 & $13,743.08$ & LSF & 0.097 & & 33.3 & 16.7 & 0.3 & 7.3 & 36.0 & 0.0 & 6.3 \\
\hline 4190.72 & $13,749.08$ & UCF & 0.210 & 44.3 & 49.7 & 14.7 & 5.3 & 2.7 & 20.0 & 0.0 & 7.7 \\
\hline 4192.63 & $13,755.33$ & LSF & 0.096 & 56.0 & 37.0 & 17.7 & 6.7 & 4.3 & 29.7 & 0.0 & 4.7 \\
\hline 4194.05 & $13,760.00$ & LSF & 0.120 & & 39.7 & 8.0 & 4.7 & 7.3 & 35.0 & 0.0 & 5.3 \\
\hline 4195.42 & $13,764.50$ & $\mathrm{CF}$ & 0.142 & & 39.3 & 20.3 & 3.3 & 13.3 & 21.7 & 0.0 & 2.0 \\
\hline 4196.79 & $13,769.00$ & $\mathrm{CF}$ & 0.167 & & 40.7 & 11.3 & 7.3 & 7.0 & 33.0 & 0.0 & 0.7 \\
\hline 4201.54 & $13,784.58$ & LSF & 0.107 & & 39.0 & 17.3 & 1.3 & 3.3 & 38.7 & 0.3 & 0.0 \\
\hline 4203.29 & $13,790.33$ & UCF & 0.127 & & 44.0 & 13.7 & 4.7 & 2.3 & 34.7 & 0.0 & 0.7 \\
\hline 4205.33 & $13,797.00$ & $\mathrm{CF}$ & 0.163 & & 43.3 & 9.7 & 12.0 & 3.3 & 30.7 & 0.3 & 0.7 \\
\hline 4206.90 & $13,802.17$ & $\mathrm{CF}$ & 0.183 & & 45.3 & 14.7 & 6.0 & 4.0 & 29.7 & 0.0 & 0.3 \\
\hline 4209.34 & $13,810.17$ & $\mathrm{CF}$ & 0.153 & 86.0 & 55.0 & 11.7 & 6.7 & 1.3 & 24.0 & 0.0 & 1.3 \\
\hline 4210.58 & $13,814.25$ & $\mathrm{CF}$ & 0.146 & 98.3 & 42.7 & 16.3 & 5.7 & 3.3 & 28.0 & 0.0 & 4.0 \\
\hline 4213.86 & $13,825.00$ & LSF & 0.159 & 96.0 & 42.0 & 17.7 & 5.3 & 1.3 & 27.0 & 0.0 & 6.7 \\
\hline 4226.18 & $13,865.42$ & $\mathrm{CF}$ & 0.114 & & 42.0 & 22.3 & 4.0 & 3.3 & 24.7 & 0.0 & 3.7 \\
\hline 4231.16 & $13,881.75$ & $\mathrm{CF}$ & 0.109 & & 37.7 & 19.7 & 3.0 & 2.7 & 29.3 & 5.3 & 2.3 \\
\hline 4232.45 & $13,886.00$ & $\mathrm{CF}$ & 0.118 & & 43.3 & 27.3 & 2.3 & 3.0 & 17.3 & 0.0 & 6.7 \\
\hline 4234.10 & $13,891.42$ & $\mathrm{CF}$ & 0.123 & 99.0 & 37.0 & 27.3 & 4.3 & 3.0 & 21.3 & 0.0 & 7.0 \\
\hline 4235.63 & $13,896.42$ & $\mathrm{CF}$ & 0.165 & & 42.3 & 16.0 & 11.3 & 3.7 & 24.3 & 0.3 & 2.0 \\
\hline 4237.76 & $13,903.42$ & UCF & 0.115 & & 45.3 & 16.3 & 5.3 & 1.3 & 31.7 & 0.0 & 0.0 \\
\hline
\end{tabular}

character of dryland fluvial systems (e.g. Bridge and Lunt 2006), continental trace fossil assemblages and their environmental implications (Hasiotis et al. 2002) and paleosol types (Retallack 1997). A total of 65 sandstone samples have been taken from the cored Skagerrak Formation intervals of the 22/29-2 well (36) and the 22/29-3 well (29) for the reservoir quality analysis of this study (Tables 1,2), and these have been selected entirely from sandstones ascribed to the fluvial channel facies (CF) (Tables 1, 2).

\subsection{Petrography}

Core sample thin sections were used to determine optical porosity, grain-size distribution and the fraction of claycoated grains. Porosity and fraction of clay-coated grains with $>80 \%$ coats were measured on blue epoxy-impregnated thin sections by point counting with 300 counts per thin section. Point counting was done using a standard petrographic microscope (Leica DM2500P and DM750P) and point counting stage (PETROG-Conway Valley Systems Limited). Grain-size distribution was analysed by using the Leica QWin (V. 3.5.0) software on thin section micrographs. Additional petrographic analysis, i.e. 
intergranular volume (IGV) (Paxton et al. 2002) and total cement volume $(C)$ (Lundegard 1992), was performed exclusively on confined fluvial channel sandstones (CF) and measured by point counting, with 300 counts per thin section. Total cement $(C)$ values comprise intergranular clay mineral cement, intergranular carbonate cement, as well as optically visible quartz and feldspar cements.

Thin sections were highly polished to $30 \mu \mathrm{m}$ and coated with carbon prior to analysis by a Hitachi SU-70 field emission gun scanning electron microscope (SEM), equipped with an energy-dispersive detector (EDS). Scanning electron microscope analyses of thin section and bulk rock samples were conducted at $5-20 \mathrm{kV}$ acceleration voltage with beam currents of 1.0 and $0.6 \mathrm{nA}$, respectively. Point analyses had an average duration of 2 min, whereas line analyses were dependent on length. SEM-EDS was used for rapid identification of chemical species and orientation on the sample. Cathodoluminescence analysis has been undertaken on selected thin sections with visible quartz overgrowths using a Gata MonoCL system with a panchromatic imaging mode operated at $8 \mathrm{kV}$.
Table 4 Non-reservoir chalk model parameters after Mallon and Swarbrick $(2008,2002)$

\begin{tabular}{|c|c|c|c|}
\hline \multicolumn{4}{|c|}{ Model parameter (Hod Formation) } \\
\hline \multicolumn{2}{|c|}{ Mechanical compaction } & \multicolumn{2}{|l|}{ Permeability } \\
\hline Porosity, \% & Depth, m & Porosity, \% & Permeability, $\log (\mathrm{mD})$ \\
\hline 70.00 & 0 & 70.00 & 1.00 \\
\hline 18.00 & 1300 & 30.00 & -1.00 \\
\hline 12.50 & 2100 & 25.00 & -3.00 \\
\hline 8.00 & 3100 & 20.00 & -5.50 \\
\hline \multirow[t]{3}{*}{5.00} & 4500 & 12.50 & -7.20 \\
\hline & & 9.00 & -7.20 \\
\hline & & 5.00 & -7.20 \\
\hline
\end{tabular}

\subsection{X-ray diffraction analysis}

X-ray diffraction (XRD) analysis (semiquantitative bulk rock and clay fraction) was conducted by X-Ray Mineral
Table 3 Lithology type and respective thickness of the modelled layers for the Seagull PetroMod models

\begin{tabular}{|c|c|c|c|c|}
\hline \multirow[t]{2}{*}{ Group/formation } & \multicolumn{2}{|c|}{ Seagull (22/29-2) } & \multicolumn{2}{|c|}{ Seagull $(22 / 29 / 3)$} \\
\hline & Thickness, m & Lithology, [-] & Thickness, m & Lithology, [-] \\
\hline Water depth & 94 & Water & 94 & Water \\
\hline Nordland & 1402 & Shale & 1406 & Shale \\
\hline Lark/Horda & 1245 & Shale & 1284 & Shale \\
\hline Tay & 37 & Siltstone & 22 & Siltstone \\
\hline Balder & 21 & Siltstone & 22 & Siltstone \\
\hline Sele & 41 & Sandstone & 38 & Sandstone \\
\hline Forties & 150 & Sandstone & 149 & Sandstone \\
\hline Lista & 39 & Silty Shale & 62 & Shale \\
\hline Maureen & 137 & Marl & 123 & Marl \\
\hline Ekofisk & 70 & Chalk & 76 & Marl \\
\hline Tor & 432 & Chalk & 432 & Chalk \\
\hline Hod & 345 & Non-Res. Chalk & 353 & Non-Res. Chalk \\
\hline Valhall & 12 & Marl & 44 & Marl \\
\hline Kimmeridge Clay & 21 & Shale & 14 & Shale \\
\hline Heather & & & 12 & Siltstone \\
\hline Pentland & 31 & Siltstone & 20 & Siltstone \\
\hline Fladen & 0 & Sandstone & 0 & Sandstone \\
\hline Joshua & 0 & Silty Shale & 0 & Silty Shale \\
\hline Josephine & 0 & Res. Sandstone & 0 & Res. Sandstone \\
\hline Jonathan & 0 & Silty Shale & 0 & Silty Shale \\
\hline Joanne & 0 & Res. Sandstone & 0 & Res. Sandstone \\
\hline Julius & 0 & Silty Shale & 0 & Silty Shale \\
\hline Judy & 378 & Res. Sandstone & 386 & Res. Sandstone \\
\hline Smith Bank & 244 & Silty Shale & 213 & Silty Shale \\
\hline Zechstein & 200 & Salt & 200 & Salt \\
\hline
\end{tabular}

The modelled key Skagerrak Formation reservoir member is in bold 
Services Ltd and has been used to identify the clay mineral quantities, composition and diagenetic alterations within the two sample sets. Selected bulk rock samples were deoiled, disaggregated and powdered to a mean particle size between 5 and $10 \mu \mathrm{m}$ for the XRD analysis. Samples were analysed by using a Philips PW1730 Generator at $2 \Theta$ (theta) angles between $4.5^{\circ}$ and $75^{\circ}$, with a step size of $0.06^{\circ}$ per second using $\mathrm{X}$-ray radiation from a copper anode at $40 \mathrm{kV}, 40 \mathrm{~mA}$, equipped with a Philips PW 1050 Goniometer with graphite monochromator and a PW1170 automatic sample changer. Identification of the minerals was achieved by using the X-ray Mineral Services Ltd inhouse 'Traces' and 'Search-Match' software to compare the X-ray diffraction pattern with the International Centre for Diffraction Data PDF-4 Minerals database. The measured maximum intensity of each mineral was compared to the standard intensity of the pure mineral. The method does not take any amorphous content into account, and the results were normalized to $100 \%$ based on the assumption that the whole mineral content accounted for the diffractogram.

Separation of the clay fraction $(<2 \mu \mathrm{m}$ fraction) was achieved by using ultrasound and centrifugation of disaggregated fresh rock samples $(5 \mathrm{~g})$ in suspension, with additional evaporation of the fluid content at $80^{\circ} \mathrm{C}$. The samples were analysed as untreated clay, after saturation with ethylene glycol vapour overnight and following heating at $380{ }^{\circ} \mathrm{C}$ for $2 \mathrm{~h}$ and $550{ }^{\circ} \mathrm{C}$ for $1 \mathrm{~h}$. The initial
Table 5 Homogenization temperatures $\left(T_{\mathrm{h}}\right)$ of aqueous (Aqu.) and oil (oil) fluid inclusions in quartz overgrowth, feldspathic and carbonate cements

\begin{tabular}{|c|c|c|c|c|c|c|c|c|}
\hline \multirow[t]{4}{*}{ FI host } & \multicolumn{8}{|l|}{ Seagull } \\
\hline & \multicolumn{4}{|l|}{$22 / 29-2$} & \multicolumn{4}{|l|}{$22 / 29-3$} \\
\hline & \multicolumn{2}{|c|}{$4174.85 \mathrm{~m}$ TVDSS } & \multicolumn{2}{|c|}{$4185.11 \mathrm{~m}$ TVDSS } & \multicolumn{2}{|c|}{$4190.72 \mathrm{~m}$ TVDSS } & \multicolumn{2}{|c|}{$4203.23 \mathrm{~m}$ TVDSS } \\
\hline & Aqu., ${ }^{\circ} \mathrm{C}$ & Oil, ${ }^{\circ} \mathrm{C}$ & Aqu., ${ }^{\circ} \mathrm{C}$ & Oil, ${ }^{\circ} \mathrm{C}$ & Aqu., ${ }^{\circ} \mathrm{C}$ & Oil, ${ }^{\circ} \mathrm{C}$ & Aqu., ${ }^{\circ} \mathrm{C}$ & Oil, ${ }^{\circ} \mathrm{C}$ \\
\hline Quartz OG & 137.9 & 75 & 134.7 & & 132.9 & 65 & 132 & \\
\hline Quartz OG & 143.4 & 72.3 & 142.3 & & 138.1 & & 128.5 & \\
\hline Quartz OG & 136.2 & 82.1 & 144 & & 141.1 & & 134.3 & \\
\hline Quartz OG & & 108.6 & 136.1 & & 135.7 & & 136.6 & \\
\hline Quartz OG & & 72.7 & 130.9 & & 139 & & 131.3 & \\
\hline Quartz OG & & 72.9 & 143.4 & & 145.4 & & 144 & \\
\hline Quartz OG & & & 139.3 & & 141.3 & & 142.6 & \\
\hline Quartz OG & & & 129.5 & & & & & \\
\hline Quartz OG & & & 134.1 & & & & & \\
\hline Feldspar & & & 135.9 & 79.3 & & & & 67 \\
\hline Feldspar & & & 136.1 & 76.4 & & & & 69.4 \\
\hline Feldspar & & & 137 & 68.4 & & & & 68.4 \\
\hline Feldspar & & & 133.7 & 76.4 & & & & 67.1 \\
\hline Feldspar & & & 132.5 & 115.7 & & & & 67.1 \\
\hline Feldspar & & & & 71.9 & & & & \\
\hline Feldspar & & & & 74.4 & & & & \\
\hline Feldspar & & & & 79.8 & & & & \\
\hline Feldspar & & & & 84.9 & & & & \\
\hline Feldspar & & & & 97.9 & & & & \\
\hline Feldspar & & & & 138.5 & & & & \\
\hline Feldspar & & & & 80 & & & & \\
\hline Feldspar & & & & 78.6 & & & & \\
\hline Feldspar & & & & 75.6 & & & & \\
\hline Feldspar & & & & 74.3 & & & & \\
\hline Carbonate & 135.8 & & & & & & & \\
\hline Carbonate & 134.5 & & & & & & & \\
\hline Carbonate & 84.8 & & & & & & & \\
\hline Carbonate & 125 & & & & & & & \\
\hline Carbonate & 116.7 & & & & & & & \\
\hline Carbonate & 85.9 & & & & & & & \\
\hline
\end{tabular}


scan for these four treatments was performed with the same machine and at $2 \Theta$ angles between $3^{\circ}$ and $35^{\circ}$ with a step size of $0.05^{\circ}$ per second using $\mathrm{X}$-ray radiation from a copper anode at $40 \mathrm{kV}, 40 \mathrm{~mA}$. The untreated samples were also analysed between $24^{\circ}$ and $27^{\circ} 2 \Theta$ at a step size of $0.2^{\circ}$ per $2 \mathrm{~s}$ to further define kaolinite/chlorite peaks. Interpretation was performed by overlaying the four diffractograms to identify the clay mineral assemblages and to assess the effect of the treatment on the clay minerals. Peak intensities were measured and analysed to indicate the relative amounts of clay minerals present and have been referenced to the total amount of clay minerals present in the bulk rock analysis.

\subsection{Fluid inclusion analysis}

Microthermometry was conducted on double-polished detached wafers to determine the conditions of cementation and evidence for formation water salinity. The wafers were firstly checked under incident UV on a petrographic microscope to determine which contain petroleum inclusions and under transmitted light to determine the distribution of both aqueous and hydrocarbon fluid inclusions for subsequent analyses. A Linkam THM600/TS90 heating-cooling stage connected to a Nikon petrographic microscope was used to obtain temperature data. Instrumental precision is $\pm 0.1{ }^{\circ} \mathrm{C}$, while accuracy, dependent on the manufacturer's stated accuracy for the calibration standards used (synthetic inclusions and pure organic compounds), is better than $\pm 0.1{ }^{\circ} \mathrm{C}$, over the range of temperatures reported here. Routinely available measurements are homogenization temperatures $\left(T_{\mathrm{h}}\right)$ and final melting temperatures $\left(T_{\mathrm{m}}\right)$. Homogenization is the conversion of multiphase inclusion contents to a single phase, usually at temperatures above room temperature. Interpreting homogenization temperatures in carbonates, sulphates and halides can be complicated because aqueous inclusions can, though not necessarily do, reset to higher temperature if they are (a) overheated beyond a threshold which is dependent on the mineral strength and inclusion geometry (Goldstein and Reynolds 1994), or (b) frozen. This can occur in the laboratory as well as through geological processes, so care is taken over the order in which analyses are made for each rock chip. If resetting has occurred, larger inclusions may give higher temperatures, homogenization temperature distributions may show a high-temperature tail, and data from paragenetically distinct settings may overlap. Final melting occurs at the disappearance of the last trace of solid in the inclusion on heating, usually after cooling an inclusion to well below room temperature. If ice is the final phase to melt, as in the present study, salinities are calculated using the equation given by Oakes et al. (1990).

\subsection{One-dimensional basin modelling}

Burial history, temperature and pore pressure evolution of the Judy Sandstone Member were modelled in one dimension using Schlumberger's PetroMod (V. 2012.2) basin modelling software. Burial history and lithology are inferred from the present-day well stratigraphy, well log lithology and lithological description of the modelled units (Fig. 3 and Table 3). The lithological unit types used in these models are mainly PetroMod (V. 2012.2) default lithology types, based on well log descriptions and core analysis reports for the two wells, and generalized Central Graben lithology descriptions (Evans et al. 2003). Exceptions are the lithology types of the Hod Formation and the Skagerrak sandstone members. The Hod chalk unit is modified to represent the North Sea non-reservoir chalk (Table 4) and to match the compaction trend and low permeability trend by Mallon and Swarbrick $(2002,2008)$.
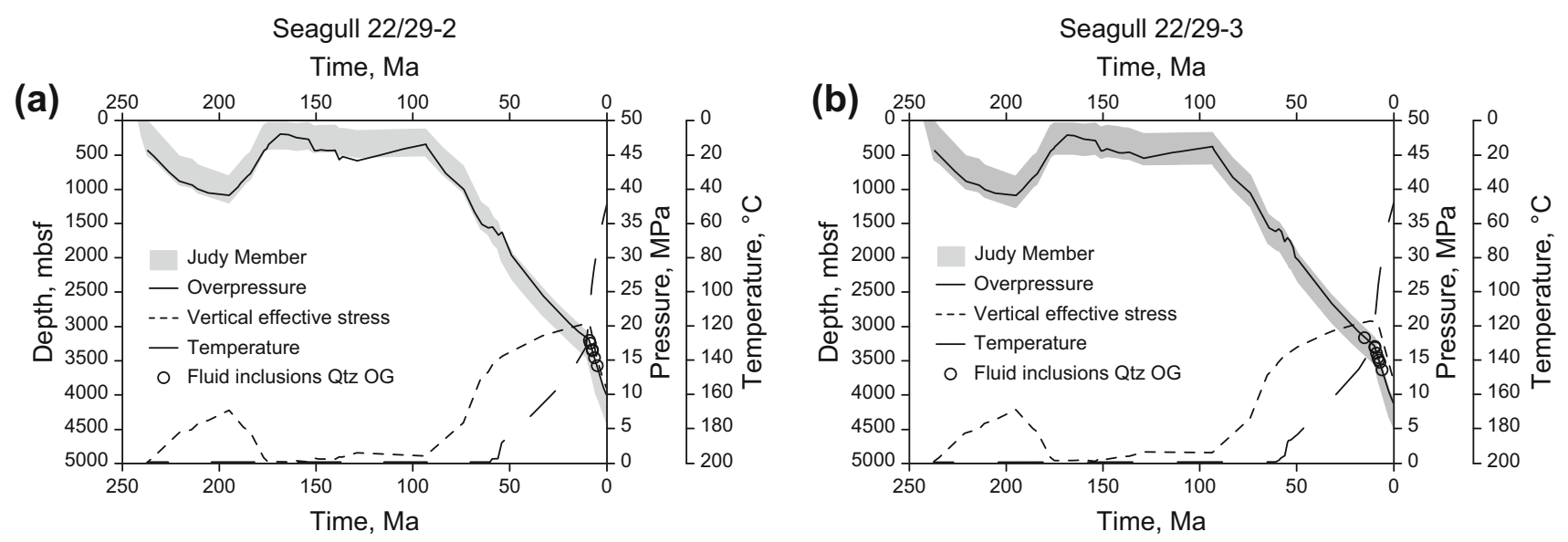

Fig. 6 Burial history of the Judy Sandstone Member of the wells 22/29-2 and 22/29-3, with temperature evolution, overpressure evolution and vertical effective stress evolution, including aqueous fluid inclusion temperatures enclosed in quartz overgrowth (Qtz OG) 


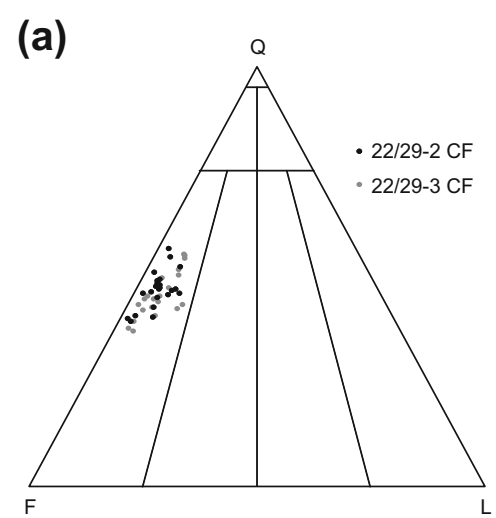

Fig. 7 a QFL diagram of the 22/29-3 (black) and 22/29-3 (grey) channel sandstones (CF), b grain-size distribution of the 22/29-2 (36 samples) and 22/29-3 (29) sample sets by facies (channel sands (CF):

The Skagerrak sandstone member lithology is a mix of lithologies ( $80 \%$ sand, $10 \%$ silt, $10 \%$ shale) in combination with the regional compaction trend for shaly sandstone by Sclater and Christie (1980), to match the general Judy Sandstone Member characteristics. The thermal upwelling basement paleo-heat flow model of Allen and Allen (2005) was used with $63-110 \mathrm{~mW} / \mathrm{m}^{2}$ (average of $80 \mathrm{~mW} / \mathrm{m}^{2}$ ) during syn-rift phases and $37-66 \mathrm{~mW} / \mathrm{m}^{2}$ (average $50 \mathrm{~mW} / \mathrm{m}^{2}$ ) during post-rift phases combined with the paleo-surface temperature history published by Swarbrick et al. (2000) and di Primio and Neumann (2008). The temperature evolution models are calibrated against present-day RFT temperature measurements corrected after Andrews-Speed et al. (1984), vitrinite reflectance data, maximum temperatures obtained from apatite fission-track analyses and paleo-temperatures obtained from fluid inclusions in mineral cements (Table 5) (Swarbrick et al. 2000; di Primio and Neumann 2008). The one-dimensional modelling provides a good insight into overpressure buildup by disequilibrium compaction and pore fluid expansion due to increasing temperature. However, the models do not include other mechanisms for generating excess pore pressure, such as fluid flow or hydrocarbon cracking, or cementational porosity loss, and are only able to take vertical stress into account. The pressure evolution models are calibrated against measured Skagerrak Formation porosities (Fig. 3) and carefully adjusted towards present-day formation pressure measurements by considering late-stage, high-temperature overpressure mechanisms (Osborne and Swarbrick 1997; Isaksen 2004). dark grey; unconfined fluvial (UCF): medium grey; lacustrine shoreface (LSF): light grey), with average sample set grain size (Av.)

\section{Burial modelling, petrography and diagenesis}

\subsection{Burial history modelling results}

The one-dimensional burial history models of the 22/29-2 and 22/29-3 wells show the evolution of burial depth, temperature, pore fluid overpressure and VES for the top of the Judy Sandstone Member throughout the geological history (Fig. 6). The Judy Sandstone Member is at maximum burial depth and temperatures $\left(>160{ }^{\circ} \mathrm{C}\right)$ at present day (Fig. 6). The Judy Sandstone Member experienced a long shallow burial phase $(\sim 150$ million years) followed by a phase of rapid burial starting between 90 and 70 Ma to their present maximum burial depth. The phase of rapid burial was accompanied by significant temperature and pore pressure increases. The burial history models show a burial rate increase from $\sim 90 \mathrm{Ma}$ onwards, leading to a present-day maximum burial depth of $\sim 4000 \mathrm{~m} \mathrm{(13,123}$ $\mathrm{ft}$ ) below seafloor (Formation top). Modelled reservoir temperatures and pore fluid overpressures increase constantly during the rapid burial phase to present-day maxima of $160{ }^{\circ} \mathrm{C}$ and $\sim 38 \mathrm{MPa}$, respectively (Fig. 6). The rapid overpressure increase in the Skagerrak Formation limits the increase in vertical effective stress (VES) during the rapid burial phase to a maximum VES of $\sim 21 \mathrm{MPa}$ at around $\sim 10 \mathrm{Ma}$ and present-day VES of $11.5 \mathrm{MPa}(22 / 29-2)$ and 12.5 MPa (22/29-3) (Fig. 6). Fluid inclusion analysis has identified the late timing of quartz cementation in the sandstones (Table 5). The aqueous homogenization temperature $\left(T_{\mathrm{h}}\right)$ for the quartz cementation is very late in the burial history ( $\sim 10 \mathrm{Ma}$; Fig. 6$)$ and concurs with the late rapid overpressure increase (from around $10 \mathrm{Ma}$ ). This late increase in overpressure is interpreted to be caused by migration of overpressured fluids and hydrocarbon cracking (Isaksen 2004; Lines and Auld 2004; Winefield et al. 

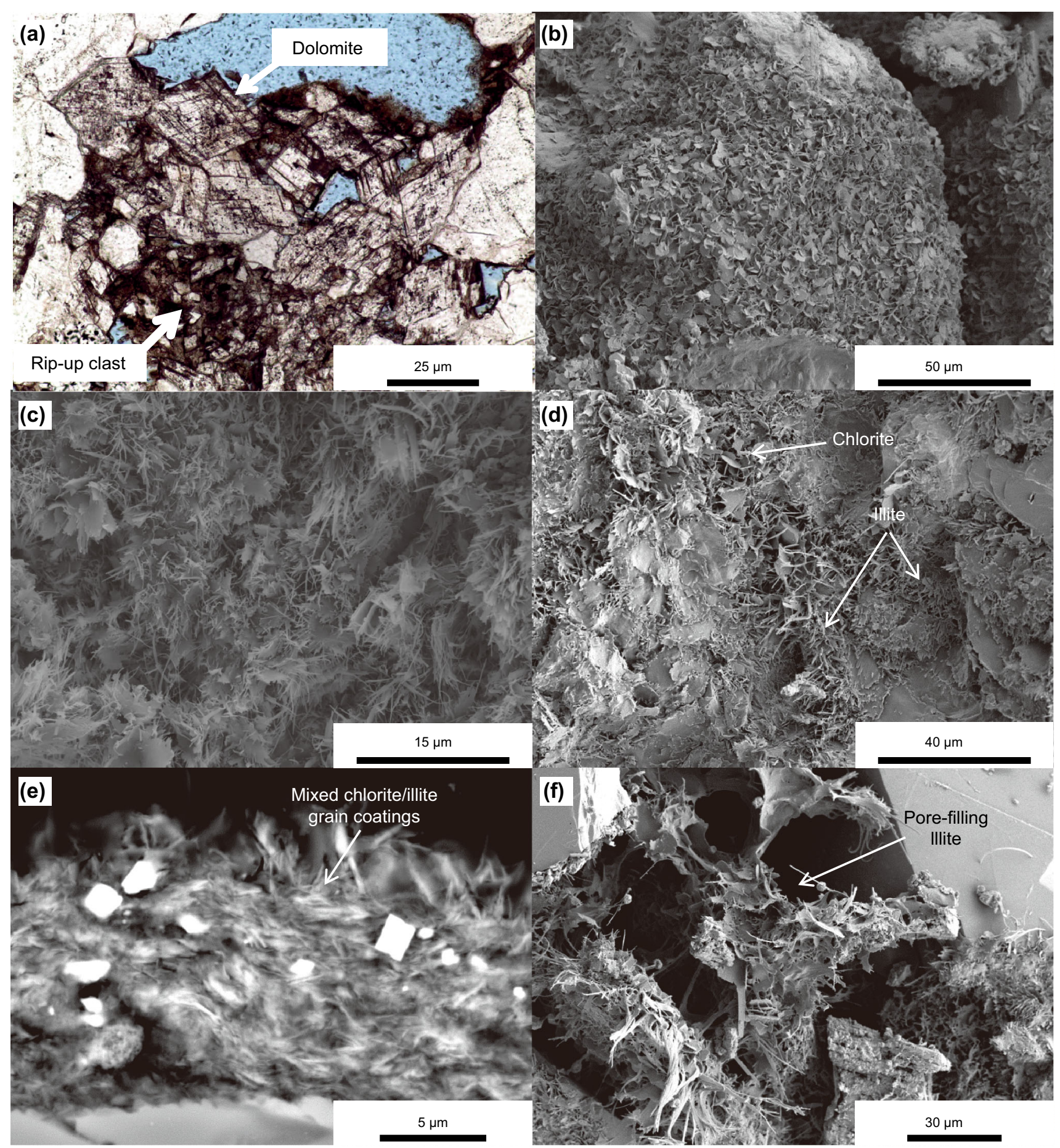

Fig. 8 Micrographs and SEM images of a calcrete/dolocrete rip-up clast with dolomite crystals [22/29-2; $4201.97 \mathrm{~m}(13,786.0 \mathrm{ft})]$; b well-developed authigenic chlorite coating [22/29-2; $4126.47 \mathrm{~m}$ $(13,538.33 \mathrm{ft})]$; $\mathbf{c}$ well-developed authigenic illite coating [22/29-3; $4206.09 \mathrm{~m}(13,799.5 \mathrm{ft})]$; d authigenic clay mineral coating,

2005), leading to the late VES reduction (Swarbrick 2012; Stricker et al. 2016a, b). comprising chlorite and illite [22/29-3; $4239.76 \mathrm{~m}(13,910.0 \mathrm{ft})]$; e cross section of a well-developed authigenic chlorite/illite coatings [22/29-3; $4198.62 \mathrm{~m}(13,775.0 \mathrm{ft})]$; f pore-filling illite/chlorite mix [22/29-3; $4198.62 \mathrm{~m}(13,775.0 \mathrm{ft})]$

\subsection{Grain size and porosity}

The 65 samples from the two samples sets ( 36 from 22/292 and 29 from 22/29-3) vary compositionally within a 
Table 6 Bulk rock XRD results for channel sandstone samples from the 22/29-2 and the 22/29-3 sample set, with quartz, K-feldspar (K-feld.), plagioclase (Plag.), illite/smectite (I/S), illite and mica (I + M), chlorite (Chl.), kaolinite (Kaol.), barite, calcite and dolomite (Dol.) in wt\%

\begin{tabular}{clllllllllll}
\hline Well & $\begin{array}{l}\text { Sample, } \\
\text { TVDSS }\end{array}$ & $\begin{array}{l}\text { Quartz, } \\
\text { wt\% }\end{array}$ & $\begin{array}{l}\text { K-feld., } \\
\text { wt\% }\end{array}$ & $\begin{array}{l}\text { Plag., } \\
\text { wt\% }\end{array}$ & $\begin{array}{l}\text { I/S, } \\
\text { wt\% }\end{array}$ & $\begin{array}{l}\text { I + M, } \\
\text { wt\% }\end{array}$ & $\begin{array}{l}\text { Chl., } \\
\text { wt\% }\end{array}$ & $\begin{array}{l}\text { Kaol., } \\
\text { wt\% }\end{array}$ & $\begin{array}{l}\text { Barite, } \\
\text { wt\% }\end{array}$ & $\begin{array}{l}\text { Calcite, } \\
\text { wt\% }\end{array}$ & $\begin{array}{l}\text { Dol., } \\
\text { wt\% }\end{array}$ \\
\hline $22 /$ & 4146.35 & 81.7 & 7.9 & 3.5 & 0.0 & 3.1 & 1.8 & 0.0 & 2.1 & 0.0 & 0.0 \\
$29-2$ & 4147.11 & 71.5 & 9.6 & 5.1 & TR & 9.4 & 2.0 & 0.0 & 2.3 & 0.0 & 0.0 \\
& 4149.78 & 58.2 & 9.5 & 6.8 & 0.0 & 17.4 & 7.6 & 0.0 & 0.6 & 0.0 & 0.0 \\
& $4151.48^{\prime}$ & 73.8 & 7.8 & 4.9 & 0.0 & 8.8 & 3.8 & 0.0 & 0.9 & 0.0 & 0.0 \\
& 4154.7 & 74.4 & 7.1 & 4.0 & 0.0 & 8.0 & 6.0 & 0.0 & 0.5 & 0.0 & 0.0 \\
$22 /$ & 4157.78 & 68.5 & 9.5 & 6.2 & 0.0 & 12.6 & 3.0 & 0.0 & 0.0 & 0.0 & 0.0 \\
$29-3$ & 4174.64 & 76.3 & 8.2 & 2.8 & TR & 9.3 & 3.3 & 0.0 & 0.0 & 0.0 & 0.0 \\
& 4176.45 & 79.6 & 6.6 & 2.2 & TR & 8.2 & 3.4 & 0.0 & 0.0 & 0.0 & 0.0 \\
& 4177.54 & 78.9 & 6.2 & 1.2 & TR & 10.8 & 2.8 & 0.0 & 0.0 & 0.0 & 0.0 \\
& 4180.18 & 73.6 & 8.5 & 0.6 & 0.0 & 15.1 & 2.2 & 0.0 & 0.0 & 0.0 & 0.0 \\
& 4181.96 & 74.6 & 7.8 & 0.0 & TR & 15.3 & 2.3 & 0.0 & 0.0 & 0.0 & 0.0 \\
& 4185.06 & 86.7 & 5.2 & 0.4 & 0.0 & 6.2 & 1.5 & 0.0 & 0.0 & 0.0 & 0.0 \\
\hline
\end{tabular}

Table 7 Clay fraction XRD results for the channel sandstone samples from the 22/29-2 and the 22/29-3 sample set, with the weight percentage of the clay fraction $(<2 \mu \mathrm{m})$, the weight percentage of the clay minerals relative to the size fraction for illite/smectite, illite, chlorite, quartz and barite, the mixed-layer ordering of illite/smectite (order; R0 random interstratified; R1 ordered interstratification; R3 long-range ordering) and the crystallinity of the clay minerals (Crys; $V W$ very well crystallized; $W$ well crystallized; $M$ moderately crystallized; $P$ poorly crystallized)

\begin{tabular}{|c|c|c|c|c|c|c|c|c|c|c|c|}
\hline \multirow[t]{2}{*}{ Well } & \multirow[t]{2}{*}{ Sample, m TVDSS } & \multirow[t]{2}{*}{$<2 \mu \mathrm{m}, \mathrm{wt} \%$} & \multicolumn{3}{|c|}{ Illite/smectite } & \multicolumn{2}{|l|}{ Illite } & \multicolumn{2}{|c|}{ Chlorite } & \multirow[t]{2}{*}{ Quartz, wt $\%$} & \multirow[t]{2}{*}{ Barite, wt $\%$} \\
\hline & & & $\mathrm{wt} \%$ & Order & $\begin{array}{l}\text { Illite, } \\
\%\end{array}$ & $\mathrm{wt} \%$ & Crys & $\mathrm{wt} \%$ & Crys & & \\
\hline \multirow[t]{6}{*}{$22 / 29-2$} & 4146.35 & 4.7 & 0.0 & & & 51.0 & $\mathrm{P}$ & 37.7 & M & 3.8 & 7.6 \\
\hline & 4147.11 & 4.1 & TR & $\mathrm{R} 1$ & $70-80$ & 47.6 & $\mathrm{P}$ & 42.4 & M & 3.9 & 6.1 \\
\hline & 4149.78 & 4.6 & 0.0 & & & 42.7 & M & 48.5 & M & 6.3 & 2.5 \\
\hline & $4151.48^{\prime}$ & 2.8 & 0.0 & & & 33.5 & $P$ & 59.6 & M & 3.5 & 3.5 \\
\hline & $4154.7^{\prime}$ & 3.0 & 0.0 & & & 15.5 & $\mathrm{P}$ & 77.9 & M & 3.9 & 2.7 \\
\hline & 4157.78 & 2.4 & 0.0 & & & 55.5 & $\mathrm{P}$ & 36.4 & M & 8.1 & 0.0 \\
\hline \multirow[t]{6}{*}{$22 / 29-3$} & 4174.64 & 3.8 & $\mathrm{TR}$ & $\mathrm{R} 1$ & $70-80$ & 40.1 & M & 54.8 & M & 5.1 & 0.0 \\
\hline & 4176.45 & 4.8 & $\mathrm{TR}$ & $\mathrm{R} 1$ & $70-80$ & 33.2 & M & 62.9 & M & 3.9 & 0.0 \\
\hline & 4177.54 & 3.0 & TR & $\mathrm{R} 1$ & $70-80$ & 32.4 & M & 63.4 & M & 4.2 & 0.0 \\
\hline & 4180.18 & 3.4 & 0.0 & & & 57.3 & M & 38.3 & M & 4.4 & 0.0 \\
\hline & 4181.96 & 3.7 & TR & $\mathrm{R} 1$ & $70-80$ & 52.0 & M & 43.9 & M & 4.1 & 0.0 \\
\hline & 4185.06 & 3.2 & 0.0 & & & 51.6 & M & 41.0 & M & 7.5 & 0.0 \\
\hline
\end{tabular}

narrow range of arkosic arenites (Fig. 7a). The grain sizes vary from very fine-grained to medium-grained sand (Fig. 7b). The sample sets show a wide range of optical porosity with $2 \%$ to $19 \%$ and $0 \%$ to $7.7 \%$ for the $22 / 29-2$ and 22/29-3, respectively, with the higher porosities occurring in the 22/29-2 sample set (Fig. 5). Point count porosity (PC) is complemented by helium core plug porosities for the core sections (measured after Boyle's law). The higher helium core plug porosities indicate the presence of significant microporosity in the sample sets (Fig. 5).

Grain-size variability and sorting is limited across all facies, with most of the sandstones being fine to very finegrained sand (Fig. 7b) (Nguyen et al. 2013; Cui et al. 2017). Confined fluvial channel sands (CF) and unconfined fluvial sands (UCF) range from very fine to mediumgrained sand (Fig. 7b), with the medium grain-sized samples of the 22/29-2 sample set represent coarser grained basal parts of the confined channel and unconfined sheet 


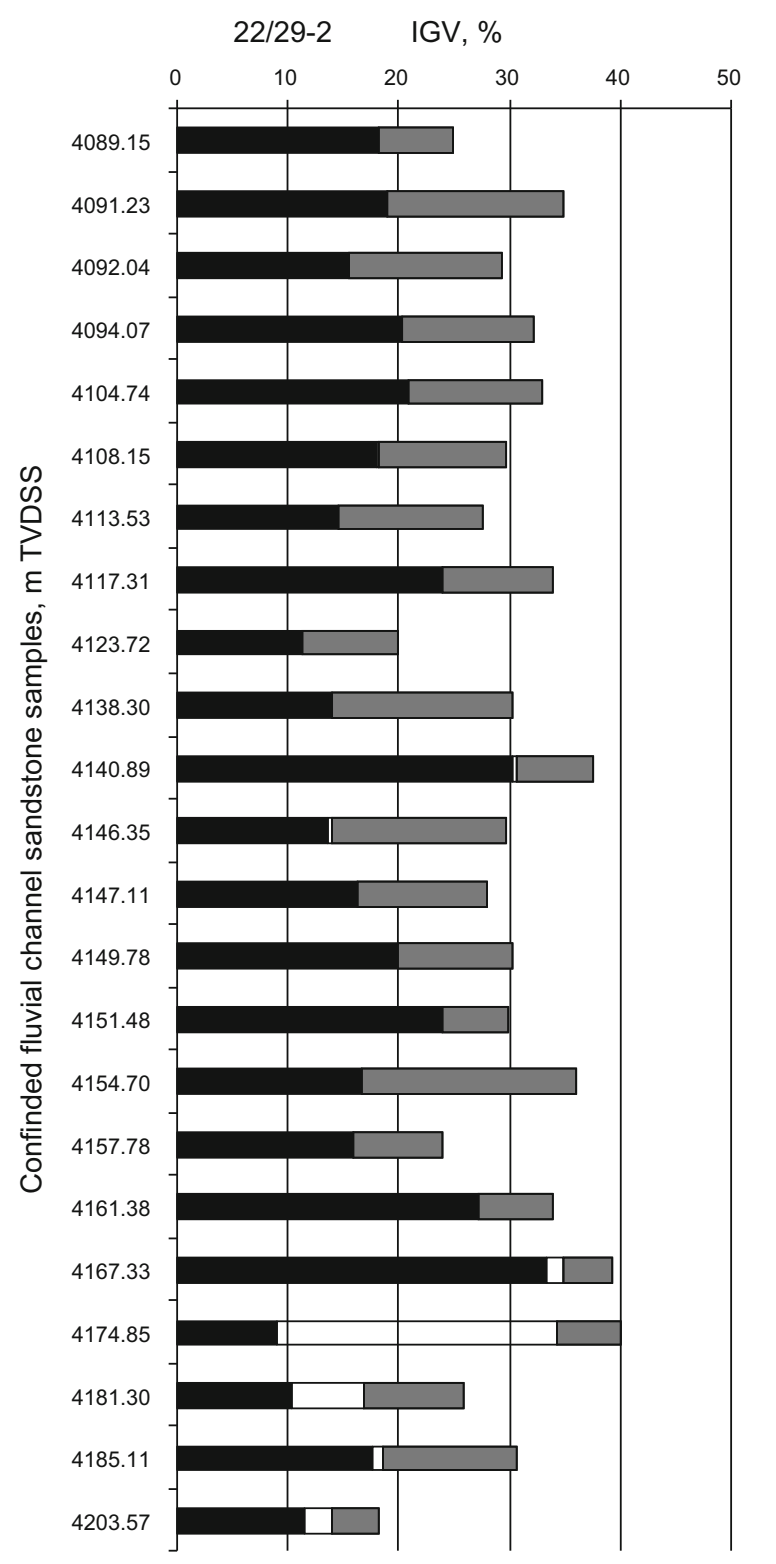

Fig. 9 Intergranular volume (IGV) of the confined fluvial channel sandstone (CF) samples of $22 / 29-2$ and $22 / 29-3$, subdivided into intergranular clay mineral cements (black), intergranular carbonate

sandbodies. The nine lacustrine shoreface samples (LSF) show in comparison with the confined fluvial channel sands (CF) and unconfined fluvial sands (UCF) marginally finer grain sizes of very fine to fine-grained sand (Fig. $7 \mathrm{~b}$ and Tables 1, 2).

\subsection{Diagenetic cements and grain coatings}

The diagenetic history of Skagerrak Formation reservoirs has been described by several authors (e.g. Smith et al. 1993; Weibel 1999; Kape et al. 2010; Nguyen et al. 2013; Stricker and Jones 2016; Stricker et al. 2016b), with the main diagenetic cements including localized carbonate,

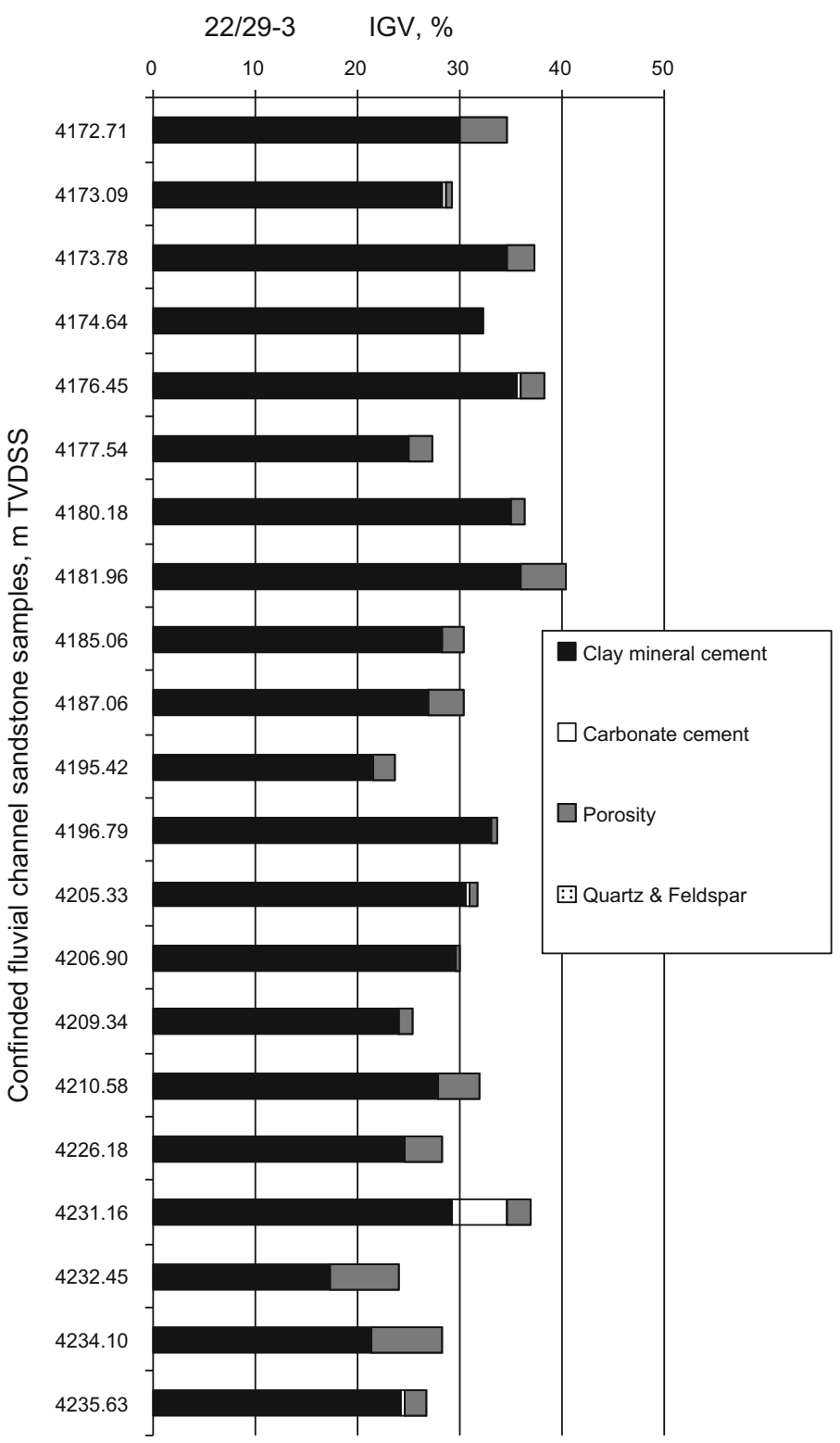

cements (white), porosity (dark grey) and quartz and feldspar cements (dotted), based on point counting. Samples names refer to true vertical depth below mean sea level in metre (m TVDSS)

authigenic clay mineral, quartz, feldspar and halite cements. Carbonate cements are reported to be localized throughout the Skagerrak Formation in the Central Graben (McKie and Audretsch 2005; McKie and Williams 2009; Nguyen et al. 2013; Cui et al. 2017) and are scarce in the Seagull sample sets. Carbonate cement is present as deformed carbonate rip-up clasts due to mechanical compaction (Fig. 8a) or as pore-filling cement. McKie and Audretsch (2005) described calcrete and/or dolocrete ripup clasts common at the channel bases and provide excellent nuclei for subsequent groundwater carbonate cementation shortly after deposition. Pore-filling carbonate cements generally show a rhombic crystal structure with a 


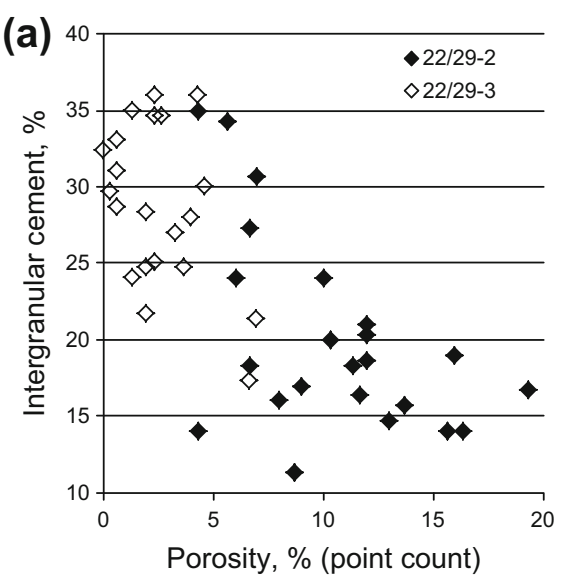

Fig. 10 a Intergranular cement and porosity (point count); b intergranular cement and intergranular volume (IGV); c compactional porosity loss (COPL) and cementational porosity loss (CEPL)

prominent cleavage pattern and tend to infill the pore space completely where present (Fig. 8a). Fluid inclusion analysis on pore-filling carbonate cements in the Seagull sample [22/29-2—4174.84 m (13,697 ft)] shows high aqueous fluid inclusions homogenization temperatures of 85-135 ${ }^{\circ} \mathrm{C}$ (Table 5).

Authigenic clay mineral cements and grain coatings, i.e. chlorite or illite, are widely reported for the Skagerrak Formation (e.g. Humphreys et al. 1989; McKie and Audretsch 2005; Nguyen et al. 2013; Grant et al. 2014; Stricker and Jones 2016; Stricker et al. 2016b), and their presence has been linked to low authigenic quartz cement volumes (e.g. Taylor et al. 2015). Authigenic clay mineral cements in the Seagull sample sets are common as grain coatings (Fig. 8b, c) or are present as intergranular and pore-filling clay cements (Fig. 8f). Detailed SEM, SEMEDS and XRD analysis shows that clay mineral cements and grain coatings consist generally of authigenic chlorite and illite (Fig. 8b, c, Tables 6, 7) or present as a mixture of authigenic chlorite and illite (Fig. 8d). SEM-EDS analysis indicates that the authigenic clay coatings are fully transformed at the present day and no-precursor clay minerals are detected. Chlorite coatings were analysed according to the Fe/Mg-ratio by Hillier and Velde (1992) and are classified as intermediate to Fe-rich according to Grigsby (2001) with a Fe/Mg-ratio of 0.43-0.49. Authigenic clay coatings are generally widespread in both Seagull sample sets and coat an average of $72.1 \%(22 / 29-2)$ and $66.4 \%$ (22/29-3) grains per sample (Tables 1,2$)$. The grain coatings are generally continuously developed with thicknesses from 5 to $20 \mu \mathrm{m}$, (average: $10 \mu \mathrm{m}$; Fig. 8e). The thickness is correlated to the illite content and increases with increasing illite content. The clay coatings commonly show a two-layered structure, with an inner layer or root zone (sensus Pittman et al. 1992) and an outer layer. The root

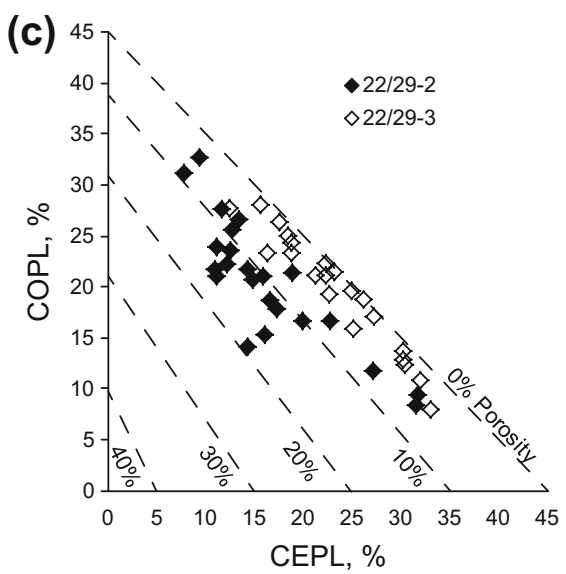

calculated according to Lundegard (1992), for the confined fluvial channel sandstone samples (CF) of the 22/29-2 and 22/29-3 wells

zone consists of densely packed and laminated crystal sheets, oriented parallel or sub-parallel to the detrital quartz grain surface. The outer coating layer commonly consists of well-defined chlorite crystals (Fig. 8b, d) or illite fibres (Fig. 8c, d).

Pore-filling clay cements in both Seagull sample sets are identified as authigenic chlorite and illite, with an increased and wider occurrence of pore-filling clay cement within the intergranular volume of the confined fluvial channel sandstones of the 22/29-3 sample set (Figs. 9, 10b). SEM analysis showed mainly fibrous illite (Fig. 8f) in association with smaller chlorite platelets in densely packed arrangements as the main pore-filling clay mineral assemblage, which can represent over $30 \%$ of the bulk rock volume and infill up to $90 \%$ of the remaining intergranular volume (Fig. 9).

Quartz cement is common as thick and blocky macroquartz overgrowths (Fig. 11a, b), present at non-coated grain surfaces (Fig. 11c) and at breaks within the clay mineral coatings, or as very thin microcrystalline quartz overgrowths (Fig. 11d). The amount of quartz cement is generally below $10 \%$ bulk volume, but can exceed $10 \%$ bulk volume in single samples. Fluid inclusion analyses on the quartz overgrowths have been undertaken on selected samples and show high homogenization temperatures. The aqueous homogenization temperatures range from 129.5 to $144{ }^{\circ} \mathrm{C}$ and from 128.5 to $145.5{ }^{\circ} \mathrm{C}$ for the $22 / 29-2$ and 22/29-3 sample sets, respectively (Table 5). Oil inclusions are generally less common, and homogenization temperatures are between 72.3 and $108.6{ }^{\circ} \mathrm{C}(22 / 29-2)$ and at $65{ }^{\circ} \mathrm{C}$ for one (22/29-3) (Table 5).

$\mathrm{K}$-feldspar dissolution and alteration is common in the Seagull sample sets (Taylor et al. 2015) and occurs generally during late burial, after the clay mineral transformation and grain coating (Fig. 11e). Original grain shapes 


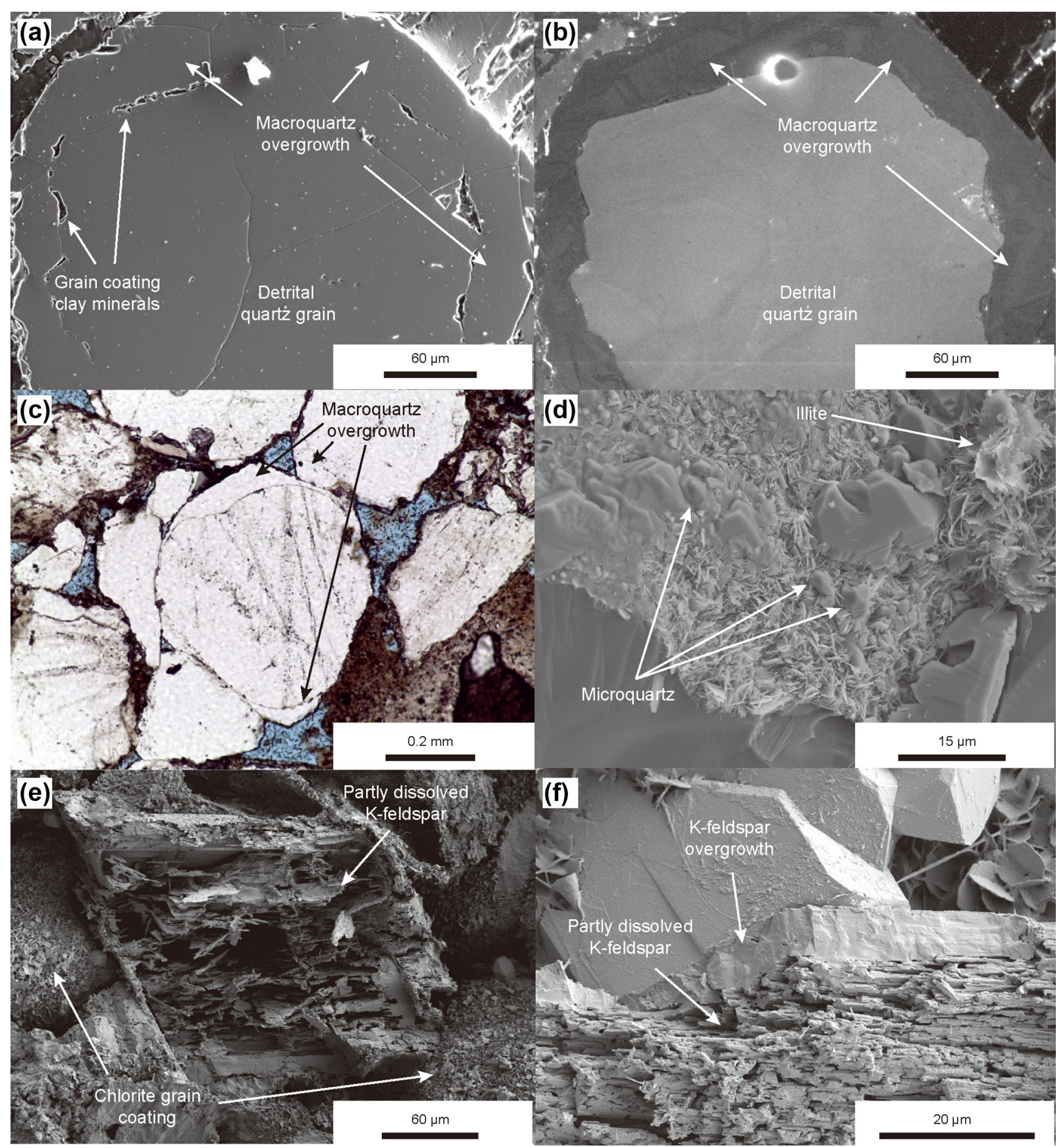

Fig. 11 CL images, micrographs and SEM images of $\mathbf{a}, \mathbf{b}$ a detrital quartz grain with macroquartz overgrowth and grain-coating clay

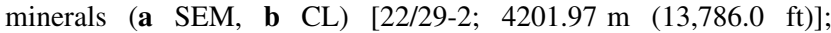
c macroquartz overgrowth on a detrital quartz grain [22/29-2;

of partly or fully dissolved grains are commonly preserved by clay mineral coatings, and late-stage blocky authigenic $\mathrm{K}$-feldspar overgrowth $(<5 \%$ bulk rock) can be observed on uncoated and partly dissolved K-feldspar grains (Fig. 11f). Aqueous fluid inclusions in feldspar
$4119.17 \mathrm{~m}(13,514.33 \mathrm{ft})]$; $\mathbf{d}$ illite grain coating with microquartz intergrowth [22/29-3; $4206.09 \mathrm{~m}(13,799.5 \mathrm{ft})]$; e partly dissolved K-feldspar (22/29-2; 13,538'4''); f partly dissolved K-feldspar with K-feldspar overgrowth [22/29-3; $4216.64 \mathrm{~m}(13,834.1 \mathrm{ft})]$

overgrowths (22/29-2) indicate cementation at high temperatures above $130{ }^{\circ} \mathrm{C}$ (Table 5). Oil inclusions encountered in feldspars show significantly lower temperatures between 67 and $138.5^{\circ} \mathrm{C}$ across the two sample sets (Table 5). Highly altered and dissolved K-feldspar grains 
Table 8 Intergranular volume (IGV), total cement $(C)$ and porosity $\left(P_{\mathrm{PC}}\right)$ values for channel sandstone samples of the 22/29-2 and 22/29-3 sample sets

\begin{tabular}{|c|c|c|c|c|c|c|c|}
\hline \multicolumn{4}{|l|}{$22 / 29-2$} & \multicolumn{4}{|l|}{$22 / 29-3$} \\
\hline Sample, m TVDSS & $\mathrm{IGV}, \%$ & $C, \%$ & $P_{\mathrm{PC}}, \%$ & Sample, m TVDSS & $\mathrm{IGV}, \%$ & $C, \%$ & $P_{\mathrm{PC}}, \%$ \\
\hline 4089.15 & 25.00 & 18.33 & 6.67 & 4172.71 & 34.67 & 30.00 & 4.67 \\
\hline 4091.23 & 35.00 & 19.00 & 16.00 & 4173.09 & 29.33 & 28.67 & 0.67 \\
\hline 4092.04 & 29.33 & 15.67 & 13.67 & 4173.78 & 37.33 & 34.67 & 2.67 \\
\hline 4094.07 & 32.33 & 20.33 & 12.00 & 4174.64 & 32.33 & 32.33 & 0.00 \\
\hline 4104.74 & 33.00 & 21.00 & 12.00 & 4176.45 & 38.33 & 36.00 & 2.33 \\
\hline 4108.15 & 29.67 & 18.33 & 11.33 & 4177.54 & 27.33 & 25.00 & 2.33 \\
\hline 4113.53 & 27.67 & 14.67 & 13.00 & 4180.18 & 36.33 & 35.00 & 1.33 \\
\hline 4117.31 & 34.00 & 24.00 & 10.00 & 4181.96 & 40.33 & 36.00 & 4.33 \\
\hline 4123.72 & 20.00 & 11.33 & 8.67 & 4185.06 & 30.33 & 28.33 & 2.00 \\
\hline 4138.30 & 30.33 & 14.00 & 16.33 & 4187.06 & 30.33 & 27.00 & 3.33 \\
\hline 4140.89 & 37.67 & 30.67 & 7.00 & 4195.42 & 23.67 & 21.67 & 2.00 \\
\hline 4146.35 & 29.67 & 14.00 & 15.67 & 4196.79 & 33.67 & 33.00 & 0.67 \\
\hline 4147.11 & 28.00 & 16.33 & 11.67 & 4205.33 & 31.67 & 31.00 & 0.67 \\
\hline 4149.78 & 30.33 & 20.00 & 10.33 & 4206.90 & 30.00 & 29.67 & 0.33 \\
\hline 4151.48 & 30.00 & 24.00 & 6.00 & 4209.34 & 25.33 & 24.00 & 1.33 \\
\hline 4154.70 & 36.00 & 16.67 & 19.33 & 4210.58 & 32.00 & 28.00 & 4.00 \\
\hline 4157.78 & 24.00 & 16.00 & 8.00 & 4226.18 & 28.33 & 24.67 & 3.67 \\
\hline 4161.38 & 34.00 & 27.33 & 6.67 & 4231.16 & 37.00 & 34.67 & 2.33 \\
\hline 4167.33 & 39.33 & 35.00 & 4.33 & 4232.45 & 24.00 & 17.33 & 6.67 \\
\hline 4174.85 & 40.00 & 34.33 & 5.67 & 4234.10 & 28.33 & 21.33 & 7.00 \\
\hline 4181.30 & 26.00 & 17.00 & 9.00 & 4235.63 & 26.67 & 24.67 & 2.00 \\
\hline 4185.11 & 30.67 & 18.67 & 12.00 & & & & \\
\hline 4203.57 & 18.33 & 14.00 & 4.33 & & & & \\
\hline
\end{tabular}

All data are point count derived can coexist in close proximity to unaltered grains, consistent with the understanding that variations in feldspar microtextures and feldspar composition exert control on their reactivity as demonstrated by Trevena and Nash (1981) and Parsons et al. (2005).

\subsection{Intergranular volume (IGV) and porosity loss by compaction versus cementation}

Intergranular volume (IGV) values (Ehrenberg 1995; Houseknecht 1987, 1988; Paxton et al. 2002) of the confined fluvial channel sandstones of the two sample sets show similar values, but comprise wide internal variations of $18.3 \%$ to $40 \%$ (22/29-2) and $23.6 \%$ to $40.3 \%$ (22/29-3) (Table 8). IGV values exclude samples with dilatation bands and are generally grain-size dependent, with the very fine-grained samples showing higher values than the fine or medium-grained samples. The comparison of the total cement $(C)$ values highlights increased cementation in the 22/29-3 (average 29.2\%) sample set compared to the 22/29-2 sample set (average 19.9\%) (Figs. 9, 10a, b). The increased pore-filling clay mineral cementation led to significant lower effective porosities in the 22/29-3 sample set (Fig. 9, Fig. 10a).

Porosity loss by compaction (COPL) and by cementation (CEPL) is calculated by the Lundegard (1992) method using total cement volume and intragranular volume (Table 8) with the initial or depositional porosity assumed to be 45\% (Beard and Weyl 1973; Chuhan et al. 2002). The calculated COPL-CEPL results indicate compaction as the main driver for porosity loss within both sample sets, with a strong addition of cementational porosity loss in the 22/29-3 sample set (Fig. 10c).

\subsection{Fractures and dilatant disaggregation bands}

Diagenetic events in the Judy Sandstone Member of the Seagull field are generally linked to the tectonic setting, structural evolution of the mini-basin and the location within the salt-walled mini-basin. The structural evolution of the Skagerrak Formation is generally controlled by the overall extensional regime within the Central Graben and the underlying Zechstein salt, even though each mini-basin has been affected differently due to the timing and magnitude of the salt movement (McKie and Audretsch 2005; 


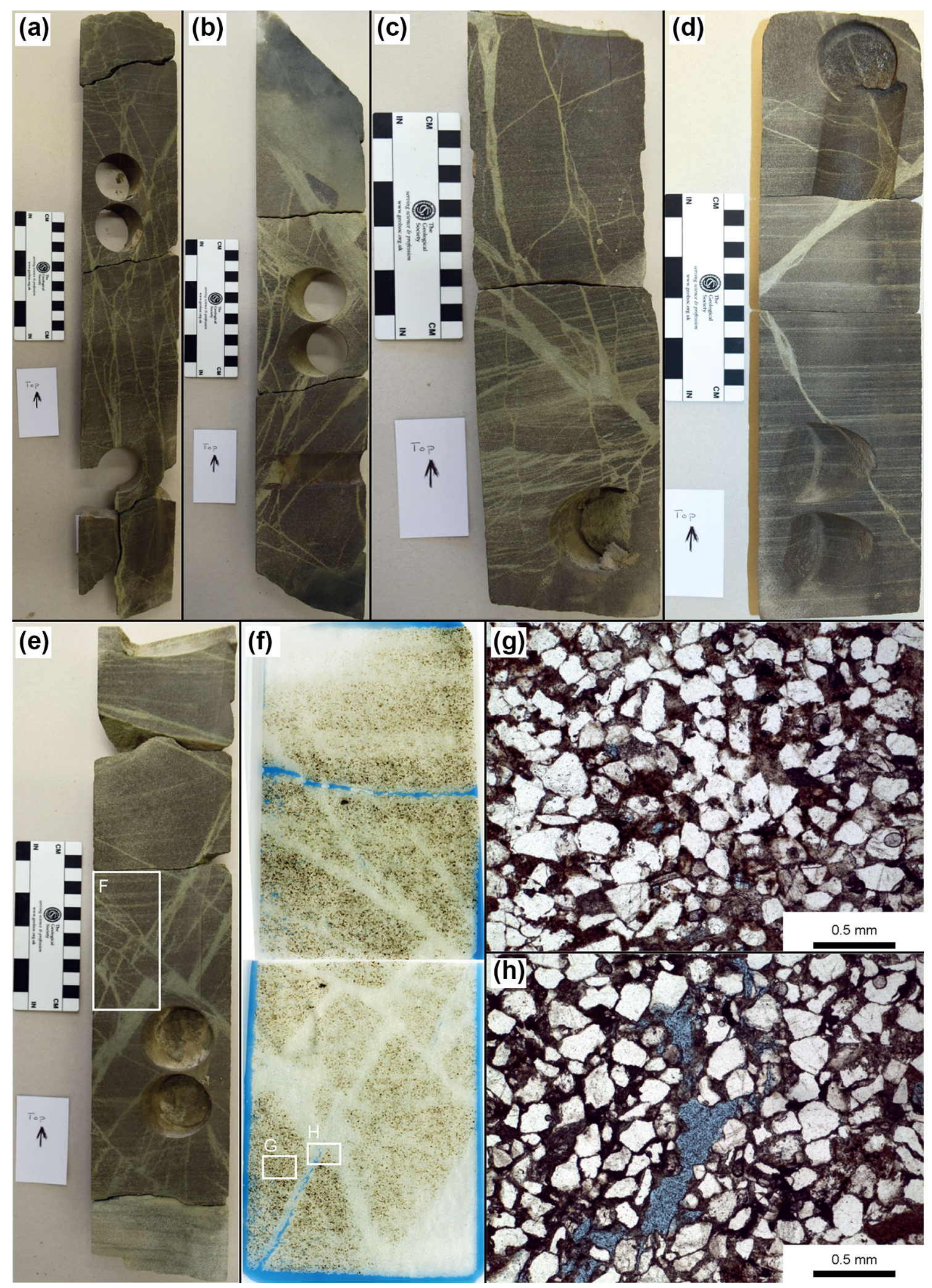


4Fig. 12 Fractures and disaggregation band distribution in core sections from the Seagull core material a 22/29-3; 4177.09 m TVDSS to $4177.70 \mathrm{~m}$ TVDSS $(13,704.36-13,706.36 \mathrm{ft}) ; \quad$ b $22 / 29-3$; $4192.90 \mathrm{~m}$ TVDSS to $4193.43 \mathrm{~m}$ TVDSS $(13,756.23-13,757.97 \mathrm{ft})$; c $22 / 29-3 ; 4208.72 \mathrm{~m}$ TVDSS to $4209.02 \mathrm{~m}$ TVDSS $(13,808.14-13,809.12 \mathrm{ft}) ; \quad$ d $22 / 29-3 ; 4209.36 \mathrm{~m}$ TVDSS to $4209.70 \mathrm{~m}$ TVDSS (13,810.24-13,811.35 ft); e 22/29-3; $4186.12 \mathrm{~m}$ TVDSS to $4187.04 \mathrm{~m}$ TVDSS $(13,733.99-13,737.01 \mathrm{ft})$; f disaggregation bands in thin section [22/29-3; $4186.37 \mathrm{~m}(13,734.81 \mathrm{ft})$ TVDSS]; $\mathbf{g}$ the grain arrangement of the host rock [22/29-3; $4186.37 \mathrm{~m}(13,734.81 \mathrm{ft})$ TVDSS]; $\mathbf{h}$ the grain arrangement of the disaggregation band with minor grain alignment and fracture porosity (blue) $[22 / 29-3 ; 4186.37 \mathrm{~m}(13,734.81 \mathrm{ft})$ TVDSS $]$

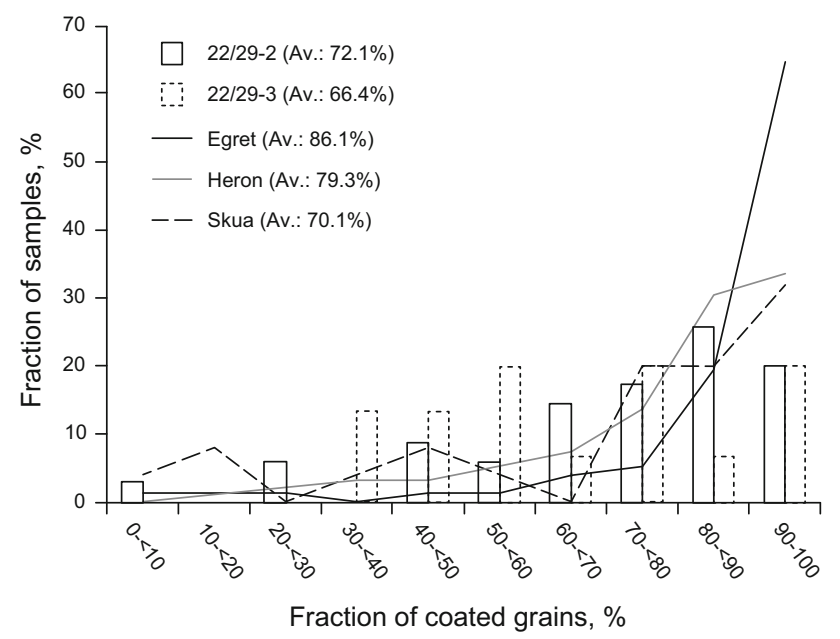

Fig. 13 Fraction of clay mineral coated grains ( $>80 \%$ coated) per 300 counts for the Seagull sample sets, in comparison with the Egret, Heron and Skua field, from Stricker et al. (2016b)

McKie et al. 2010). The Seagull mini-basin or pod is grounded on an edge of one of the underlying Rotliegend basement blocks (Fig. 2a, b) and is tilted as a result of the ongoing evacuation of salt from under the subsiding minibasin (Helgeson 1999; McKie and Audretsch 2005). The grounding and ongoing evacuation of salt from below the mini-basin led to increased fracturing and faulting of the semi-consolidated Skagerrak Formation sediments at the mini-basin flanks in comparison with the mini-basin centre and the reshaping of the sediment body and internal stress and strain changes. The movement of the large salt walls influenced deposition throughout the Smith Bank Formation of the Early Triassic and continued influencing sedimentation of the Skagerrak Formation until the late Triassic (end Norian, Fig. 3).

Core material of the 22/29-3 well shows dense patterns of fractures (e.g. Fig. 12). Orientation and aperture of the infilled fractures varies throughout the core material, with fracture apertures from 1 to $50 \mathrm{~mm}$ (Fig. 12a-e). Thin sections of infilled fractures and adjacent host rock material were prepared for further analysis of the fractures and fracture infill (4177.44 m TVDSS (13,705.5 ft); $4186.37 \mathrm{~m}$ TVDSS (13,734.8 ft); $4191.18 \mathrm{~m}$ TVDSS $(13,750.6 \mathrm{ft})$; $4193.26 \mathrm{~m}$ TVDSS $(13,757.4 \mathrm{ft}) ; 4202.43 \mathrm{~m}$ TVDSS [13,787.5 ft); $4208.92 \mathrm{~m}$ TVDSS $(13,808.8 \mathrm{ft})]$. The fractures are generally characterized by small shear offsets and show no indicators of cataclastic deformation (fractured grains or reduced grain size) or grain dissolution (Fig. 12f, h). Fracture infills contain arkosic sands with similar grainsized to the host rock material and intergranular clay mineral cements identical to the host rock material (Fig. 12g, h). Minor shear-related grain alignment can be observed within the fractures, but no carbonate or quartz cementation could be observed (Fig. 12f, h).

Fractures within the 22/29-3 core material are classified as dilational shear bands (shear-related, dilatant, disaggregation bands) (Du Bernard et al. 2002; Fossen et al. 2007; Fossen and Bale 2007). Dilatant disaggregation bands are commonly reported for poorly consolidated sandstones at surface or near-surface conditions $(<1000 \mathrm{~m})$, where minor vertical effective stress is applied to the grain framework (Mandl et al. 1977; Du Bernard et al. 2002; Fossen et al. 2007; McKie et al. 2010). Dilatant disaggregation bands are commonly characterized by small shear displacement, a reduced grain framework density, larger pores and a small porosity increase of up to $8 \%$ with respect to the host rock (Antonellini et al. 1994; Du Bernard et al. 2002; Fossen and Bale 2007). Increased porosity and decreased grain framework density make dilatant disaggregation bands a suitable pathway for meteoric water influx (Du Bernard et al. 2002), which is commonly associated by clay mineral infiltration and diagenetic alterations (Matlack et al. 1989).

\section{Discussion}

\subsection{Clay mineral cementation and reservoir quality}

The amount, distribution and morphology of clay minerals can have significant effects on the reservoir quality of sandstones. Infiltrated clay minerals and authigenic clay mineral cements can enhance or reduce effective porosity and permeability. The development of clay mineral coatings in sandstones is for example, often reported to be closely linked with the absence of extensive quartz cementation and porosity preservation (e.g. Matlack et al. 1989; Billault et al. 2003; Ajdukiewicz and Larese 2012; Taylor et al. 2015). Pore-filling clay mineral cements, however, are known to decrease effective porosity and to reduce the reservoir permeability significantly (e.g. Worden and Morad 2003; Wilson et al. 2014). Authigenic clay mineral cements are widely reported for the Skagerrak 


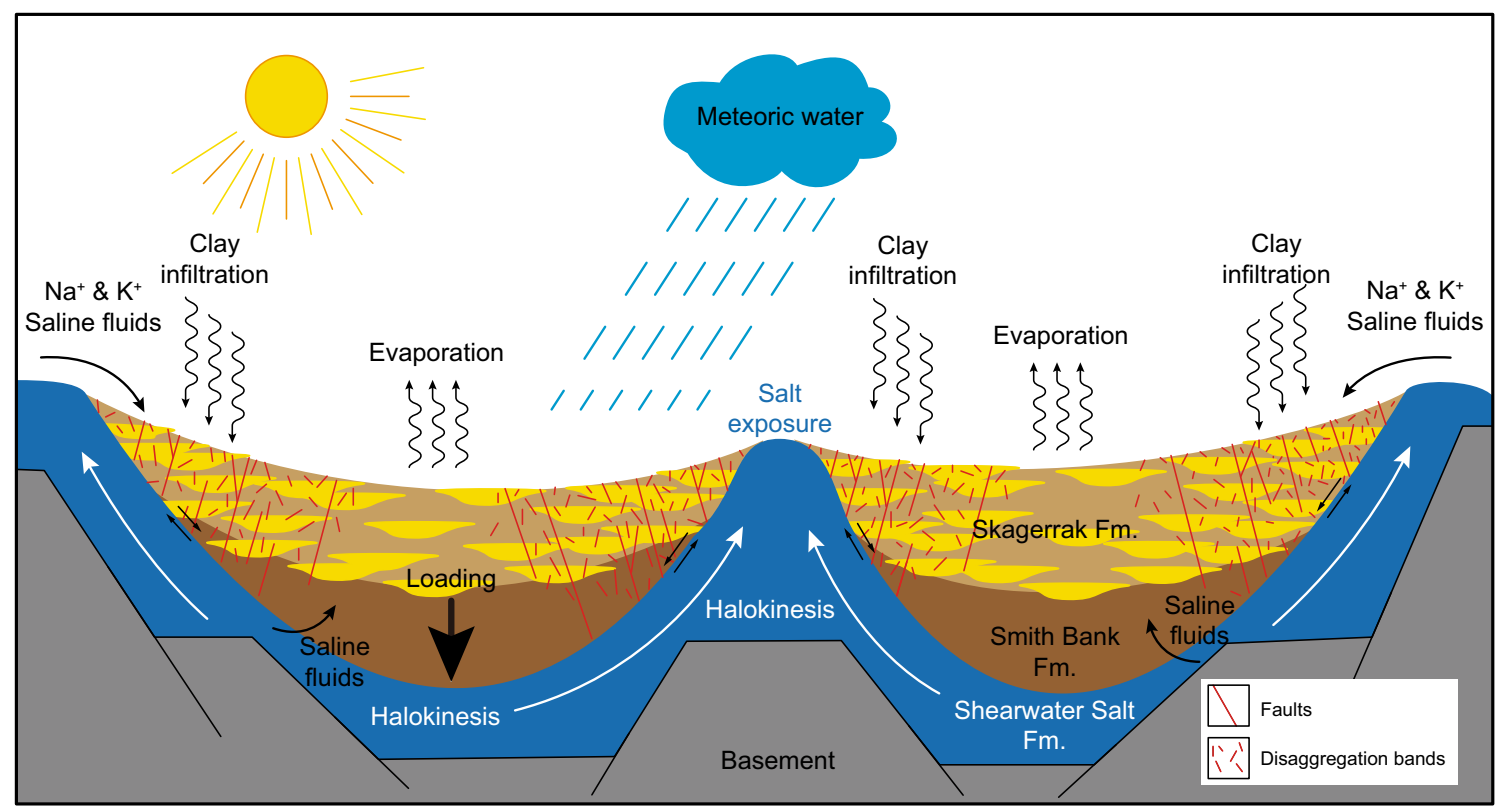

Fig. 14 Schematic illustration of salt-walled mini-basin and reservoir quality influencing processes

Formation, especially grain-coating chlorite which have been linked to the absence of extensive quartz cementation in the Skagerrak Formation sandstones (e.g. Humphreys et al. 1989; Nguyen et al. 2013; Taylor et al. 2015; Stricker et al. 2016b; Stricker and Jones 2016).

The general clay mineral assemblage in the 22/29-2 and 22/29-3 sample sets consists of authigenic chlorite and authigenic illite. The ratio between chlorite and illite varies from $83 \%$ and $17 \%$ to $40 \%$ and $60 \%$ with an average $54 \%$ to $46 \%$, respectively. Kaolinite, as reported by Taylor et al. (2015), has not been observed in the sample sets (Table 6). The authigenic clay mineral cements are common as clay mineral grain coatings (Fig. 8b, c) and pore-filling clay aggregates (Fig. 8f). Clay mineral coatings are commonly well developed and tend to cover around $72.1 \%$ (22/29-2) and $66.4 \%$ (22/29-3) of the detrital grains (Fig. 13). The authigenic clay mineral coatings tend to enhance the reservoir quality, where they are well developed and fully coating (Fig. 8b, c, d), inhibition of quartz cement is noted. However, where the authigenic coatings are poorly developed, quartz cement nucleated and the pore space has been infilled by macroquartz cements (Fig. 11a, b, c). A comparison of the authigenic clay mineral coatings between the sample sets of the Heron, Egret, Seagull and Skua fields (Fig. 1b) shows a lower fraction of coated grains and lower surface coverage rates for the Seagull sample sets (Fig. 13). This is reflected by an increase of pore-filling macroquartz cement in comparison with the Heron, Egret or Skua fields (Taylor et al. 2015). Pore-filling clay mineral cements within the confined fluvial channel sandstones of the Seagull sample sets are either authigenic illite (Fig. 8f) or a mixture of authigenic illite and chlorite. The porefilling clay mineral cements can occupy up to $90 \%$ of the remaining intergranular volume (Fig. 9) and reduce effective porosity and permeability significantly within the channel sandstones of the Judy Sandstone Member.

The authigenic clay mineral cements are postulated to neo-formed from post-depositional, infiltrated allogenic clay minerals. Post-depositional clay infiltration by muddy water has been described as an effective mechanism to emplace allogenic clay mineral aggregates and allogenic clay mineral coats post-depositional into sand in arid and semiarid climates (Matlack et al. 1989; Moraes and de Ros 1990; Worden and Morad 2003; Ajdukiewicz et al. 2010). The allogenic clay minerals are infiltrated by meteoric water during rain or flood events into semi-consolidated sands (Worden and Morad 2003; McKie et al. 2010), where fractures and disaggregation bands increase the infiltration depth (Fig. 12). High amounts of infiltrated allogenic clay minerals resulted in thick allogenic clay mineral coatings, allogenic clay mineral bridges between clay mineral coatings and pore-filling allogenic clay mineral aggregates (Matlack et al. 1989; Moraes and de Ros 1990). Allogenic clay minerals tend to transform with ongoing burial and increasing temperatures along existing structures into authigenic chlorite and illite which led to present-day authigenic clay coatings (Fig. 8b, c, d), pore-bridging clay structures and pore-filling clay aggregates (Fig. 8f).

However, alternative formation scenarios for the authigenic pore-filling clay mineral cements are possible, such as illitization of kaolinite in combination with $\mathrm{K}$-feldspars (Bjørkum and Gjelsvik 1988; Chuhan et al. 2000; Worden 


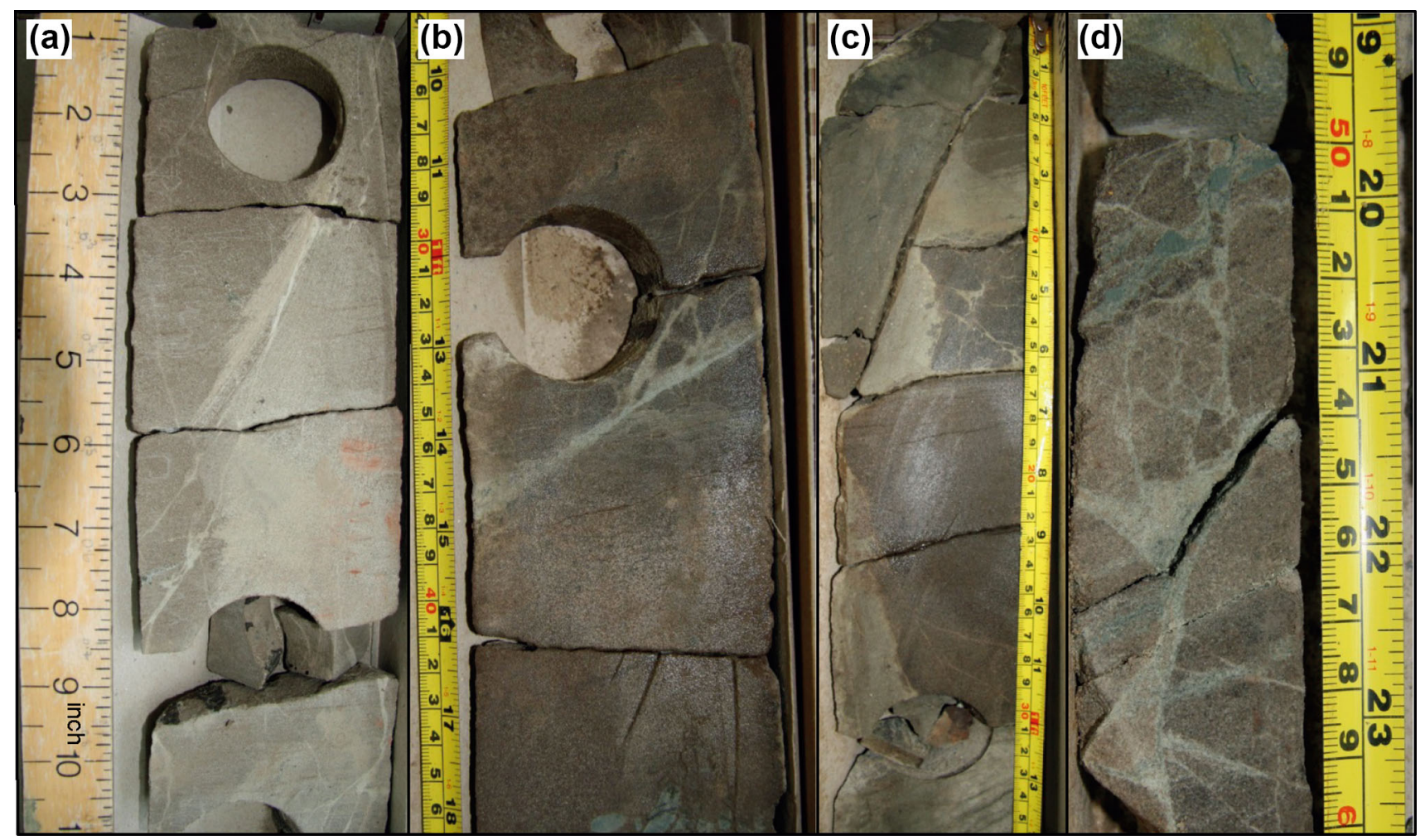

Fig. 15 Fractures and disaggregation band distribution in core sections from Huntington (22/14b-4) and Fiddich (22/19-1) core material a 22/14b-4; 3726.79-3727.09 m MD (12,227-12,228 ft);

and Morad 2003; Franks and Zwingmann 2010). Kaolinite and K-feldspar are known to react to fibrous illite at low temperatures $\left(\sim 50{ }^{\circ} \mathrm{C}\right)$ (Bjørkum and Gjelsvik 1988) and increase their reactivity with increasing temperatures $\left(>70{ }^{\circ} \mathrm{C}\right)$ with illitization being pervasive at temperatures greater than $130{ }^{\circ} \mathrm{C}$ (Worden and Morad 2003). Kaolinite and K-feldspar could have transformed to pore-filling fibrous illite and quartz in the Judy Sandstone Member, until one of the reactants was completely consumed (Chuhan et al. 2000; Franks and Zwingmann 2010). Although, no remnants of kaolinite were observed in the Seagull sample sets, the eogenetic formation of kaolinite from feldspar dissolution cannot be excluded. Kaolinite is not found in the Skagerrak Formation of the area (e.g. Humphreys et al. 1989; Nguyen et al. 2013; Stricker et al. 2016b), and no chemical or structural remnants of kaolinite could be detected during XRD, SEM or SEM-EDS analysis (Table 7), so it is either completely illitised or was not present initially. Traces of illite/smectite have been detected in the sample sets (Table 7), which points towards mechanically infiltrated smectite clay minerals as a main precursor material for the authigenic clay mineral assemblage of the Seagull sample sets.

Variations in the amount and distribution of the authigenic clay minerals between the 22/29-2 and 22/29-3 b 22/14b-4; 37,270.09-3727.40 m MD (12,228-12,229 ft); c 22/14b4; 3754.53-3754.83 m MD (12,318-12,319 ft); d 22/19-1; 3506.11-3506.42 m MD (11,503-11,504 ft)

sample sets are proposed to relate to variable amounts of infiltrated clay minerals through fractures and disaggregation bands (Fig. 14). Intergranular and pore-filling clay mineral aggregates are common in both sample sets, but are particularly abundant in the 22/29-3 sample set (Table 2, Fig. 10b). Even though the authigenic clay mineral aggregates comprise significant microporosity (Fig. 5), they reduce effective porosity by infilling the open pore space, and tend to decrease fluid flow significantly by blocking pore throats. McKie and Audretsch (2005) reported significant permeability reductions (hundreds of $\mathrm{mD}$ ) in the channel sandstones of the Seagull field, in comparison with the Heron field $(>10,000 \mathrm{mD})$, where the clay minerals tend to line the pore space and pore-filling clay aggregates are less common (Stricker et al. 2016b).

\subsection{Spatial variations of reservoir quality within salt-walled mini-basins}

The Seagull mini-basin formed due to differential loading and withdrawal of Late Permian Zechstein salt. The Permian salt has negligible shear strength on long timescales, and hence, it deforms by differential sedimentary or tectonic loading. Coeval halokinesis during mini-basin infill and post-depositional halokinesis affected reservoir quality 
of the confined channel sandstones due to spatially variability of mineral alterations, induced by spatial variations in the pore fluid chemistry, depending on the proximity to the Permian salt (meteoric to hypersaline pore fluids) (Fig. 14) and halokinesis-induced faults and fractures (syndepositional and/or post-depositional) which enhance or reduce fluid flow locally (Fig. 12).

The Judy Sandstone Member within the Seagull minibasin shows strong reservoir quality variations between the 22/29-2 and 22/29-3 wells. The 22/29-3 sample set shows generally lower porosities and poorer reservoir quality than the 22/29-2 sample set (Fig. 5). Both sample sets have undergone a similar burial history, reflecting similar VES and temperature histories (Fig. 6) and show comparable IGV values (Table 8), with similar average values of $30.3 \%(22 / 29-2)$ and $32.5 \%$ (22/29-3). The intergranular cement volumes, however, show significant variations between the two sample sets (Figs. 9, 10 and Table 8) and indicating a strong relationship between reservoir quality, diagenesis and the degree to which clay infiltration has influenced early fabric. Detailed petrographic analysis of the confined fluvial channel sandstone samples shows significant $(>10 \%)$ more authigenic clay mineral cements within the 22/29-3 samples (Figs. 9, 10a, b). Variations in the distribution of the clay mineral cement correlate to the increased occurrence of fractures and disaggregation bands towards the salt wall at the mini-basin margin (Fig. 4).

Disaggregation bands and fractures can be encountered in both cores, but are significantly more common in the 22/29-3 core proximal towards the salt wall (Figs. 4, 12). Faulting of mini-basin infill can commonly be encountered proximal to mini-basin margins or to tectonically active salt walls, e.g. the Huntington field (22/14b-4) or the Fiddich field (22/19-1) (Figs. 4, 15). The contemporaneous salt movement and post-depositional salt withdrawal at the mini-basin flanks lead to changes in the internal stresses of the sediment bodies and to higher densities of fractures and disaggregation bands in the sedimentary sequence (Fig. 14) (e.g. Fox 1998; Mark and Rowan 1999). Fractures and disaggregation bands represent ideal pathways for meteoric fluids and generate local fluid chemistry variations within the sediment body and the mini-basin. The higher fracture densities at the marginal areas proximal to the salt walls hold the potential for increased meteoric influx, hypersaline pore fluid chemistry due to the proximity to salt bodies, increased clay mineral infiltration and localized pore fluid changes during shallow burial. This leads to diagenetic variations in the mineral and especially clay mineral assemblage during shallow and deep burial. The higher density of disaggregation bands at the mini-basin margin can also complicate fluid flow and reservoir quality prediction as fractures, faults and disaggregation bands create a complex system of permeable fluid pathways and cemented baffles at deeper burial (e.g. Fossen et al. 2007).

\subsection{Implications for exploration in salt-walled mini-basins in the North Sea}

Hydrocarbon exploration in salt basins can be challenging due to the wide range of potential tectonostratigraphic controls on the temporal and spatial facies distribution and the diagenetic interplay between salt and sediments during burial (e.g. Smith et al. 1993; Barde et al. 2002; Matthews et al. 2007). The tectonic effects of halokinesis on saltwalled mini-basins are significant and can influence the shape and orientation of the mini-basin, as well as the sediment deposition and diagenetic alteration within it. Salt-walled mini-basins are commonly faulted and tilted in the Central North Sea (McKie et al. 2010), which creates structural highs at the marginal areas of the mini-basin. These structural highs can form structural traps with up-dip closure against impermeable salt and provide excellent hydrocarbon plays. However, this research has highlighted strong intra-basin reservoir quality variations within the mini-basins, due halokinesis and diagenetic alterations. Banham and Mountney (2013b) have highlighted depositional variations within salt-walled mini-basins and have shown higher reservoir potential with more stacked channel sandstones for the mini-basin centres. This research has taken spatial reservoir quality analysis even further and provides valuable insights into the diagenesis of the channel sandstones. It has been shown that fluvial channel sandstones in the central areas of mini-basins exhibit higher reservoir quality due to less clay mineral cementation and lower density of fracture and disaggregation bands.

Central areas of salt-walled mini-basins exhibit better reservoir quality due to higher ratios of stacked channel sandstones, less clay infiltration and less diagenetic alteration, whereas marginal areas provide excellent traps but poorer reservoir quality.

\section{Conclusions}

(1) Excellent reservoir quality with anomalously high porosities of up to $20 \%$ at burial depths of $>4000 \mathrm{~m}$ $(>13,123 \mathrm{ft}$ ) is preserved in Skagerrak Formation of the Seagull field (UK Quadrant 22).

(2) Reservoir quality varies significantly, with maximum porosity from $8 \%$ to $20 \%\left(P_{\mathrm{PC}}\right)$, within confined channel sandstones in the salt-walled mini-basin despite similar burial and diagenetic histories. 
(3) An increase in fracture and disaggregation band density proximal to salt walls has led to increase clay mineral infiltration and subsequent porosity reduction due to higher fractions of pore-filling authigenic chlorite and illite within fluvial channel sandstones proximal to the salt walls.

(4) Reservoir quality appears to be influenced by spatial positioning within salt-walled mini-basins. Within the fluvial channel facies, reservoir quality can be shown to vary in relation to distance from salt walls, with lower porosity adjacent to the salt walls.

Acknowledgements The research consortium GeoPOP sponsored by BG, BP, Chevron, ConocoPhillips, DONG Energy, E. ON, ENI, Petrobras, Petronas, Statoil and Tullow Oil at Durham University is thanked for funding this research. We acknowledge support from the BGS for access to core material from the Seagull wells and X-Ray Mineral Services Ltd for XRD analysis. Norman Oxtoby is thanked for conducting the fluid inclusion analysis. We thank András Fall, Philip D. Heppard, Ben Kilhams, Mark Osborne, Andrew R. Thomas and Guanghui Yuan for their suggestions and constructive reviews to help improve the manuscript. The results presented have been improved through collaborative discussions with many colleagues including Peter Andras, Andy Aplin, Mark Brodie, Jon Gluyas, Neil Goulty, Neil T. Grant, Sean O’Neil and Shanvas Sathar.

Open Access This article is distributed under the terms of the Creative Commons Attribution 4.0 International License (http://crea tivecommons.org/licenses/by/4.0/), which permits unrestricted use, distribution, and reproduction in any medium, provided you give appropriate credit to the original author(s) and the source, provide a link to the Creative Commons license, and indicate if changes were made.

\section{References}

Ajdukiewicz JM, Larese RE. How clay grain coats inhibit quartz cement and preserve porosity in deeply buried sandstones: observations and experiments. Am Assoc Pet Geol Bull. 2012;96(11):2091-119.

Ajdukiewicz JM, Nicholson PH, Esch WL. Prediction of deep reservoir quality using early diagenetic process models in the Jurassic Norphlet Formation, Gulf of Mexico. Am Assoc Pet Geol Bull. 2010;94:1189-227. https://doi.org/10.1306/ 04211009152

Allen PA, Allen JR. Basin analysis-principles and applications. 2nd ed. Oxford: Wiley-Blackwell; 2005. p. 562.

Andrews-Speed CP, Oxburgh ER, Cooper BA. Temperatures and depth-dependent heat flow in western North Sea. AAPG Bulletin. 1984;68(11):1764-81.

Antonellini MA, Aydin A, Pollard DD. Microstructure of deformation bands in porous sandstones at Arches National Park, Utah. J Struct Geol. 1994;16(7):941-59.

Archer SG, Alsop GI, Hartley AJ, Grant NT, Hodgkinson R. Salt tectonics, sediments and prospectivity: an introduction. Geol Soc London Spec Publ. 2012;363(1):1-6.

Banham SG, Mountney NP. Evolution of fluvial systems in saltwalled mini-basins: a review and new insights. Sediment Geol. 2013a;296:142-66.
Banham SG, Mountney NP. Controls on fluvial sedimentary architecture and sediment-fill state in salt-walled mini-basins: Triassic Moenkopi Formation, Salt Anticline Region, SE Utah, USA. Basin Res. 2013b;25(6):709-37.

Barde J-P, Chamberlain P, Galavazi M, Gralla P, Harwijanto J, Marsky J, et al. Sedimentation during halokinesis: PermoTriassic reservoirs of the Saigak Field, Precaspian Basin, Kazakhstan. Pet Geosci. 2002;8(2):177-87.

Beard DC, Weyl PK. Influence of texture on porosity of unconsolidated sands. Am Assoc Pet Geol Bull. 1973;57(2):349-69.

Billault V, Beaufort D, Baronnet A, Lacharpagne JC. A nanopetrographic and textural study of grain-coating chlorites in sandstone reservoirs. Clay Miner. 2003;38(3):315-28.

Bishop DJ. Regional distribution and geometry of salt diapirs and supra-Zechstein Group faults in the western and central North Sea. Mar Pet Geol. 1996;13(4):355-64.

Bjørkum PA, Gjelsvik N. An isochemical model for formation of Authigenic Kaolinite, K-feldspar and illite in sediments. SEPM J Sediment Res. 1988;58(3):506-11.

Bridge JS, Lunt IA. Depositional models of braided rivers. In: Sambrook-Smith GH, Best JL, Bristow CS, Petts GE, editors. Braided rivers: process, deposits, ecology and management. Oxford: Blackwell Publishing Ltd; 2006. p. 11-49. https://doi. org/10.1002/9781444304374.ch2.

Brown S. Stratigraphy of the oil and gas reservoirs: UK Continental Shelf. Geological Society, London, Memoirs, 1991;14:9-18. https://doi.org/10.1144/GSL.MEM.1991.014.01.02.

Chuhan FA, Bjørlykke K, Lowrey C. The role of provenance in illitization of deeply buried reservoir sandstones from Haltenbanken and north Viking Graben, offshore Norway. Mar Pet Geol. 2000;17(6):673-89.

Chuhan FA, Kjeldstad A, Bjørlykke K, Høeg K. Porosity loss in sand by grain crushing-experimental evidence and relevance to reservoir quality. Mar Pet Geol. 2002;19(1):39-53.

Cui Y, Jones SJ, Saville C, Stricker S, Wang G, Tang L, et al. The role played by carbonate cementation in controlling reservoir quality of the Triassic Skagerrak Formation, Norway. Mar Pet Geol. 2017;85:316-31.

di Primio R, Neumann V. HPHT reservoir evolution: a case study from Jade and Judy fields, Central Graben, UK North Sea. Int J Earth Sci. 2008;97(5):1101-14.

De Jong M, Smith D, Nio SD, Hardy N. Subsurface correlation of the Triassic of the UK southern Central Graben: new look at an old problem. First Break. 2006;24(6):103-9.

Du Bernard X, Eichhubl P, Aydin A. Dilation bands: a new form of localized failure in granular media. Geophys Res Lett. 2002;29(24):21-9.

Ehrenberg SN. Measuring sandstone compaction from modal analyses of thin sections; how to do it and what the results mean. J Sediment Res. 1995;65(2a):369-79.

Erratt D, Thomas GM, Wall GRT. The evolution of the Central North Sea Rift. Pet Geol Northwest Eur. In: Proceedings of 5th conference geological society of London; 1999. p. 63-82.

Evans D, Graham C, Armour A, Bathurst P, editors. The Millennium Atlas: petroleum geology of the central and northern North Sea. London: Geological Society; 2003.

Fossen H, Bale A. Deformation bands and their influence on fluid flow. Am Assoc Pet Geol Bull. 2007;91(12):1685-700.

Fossen H, Schultz RA, Shipton ZK, Mair K. Deformation bands in sandstone: a review. J Geol Soc Lond. 2007;164(4):755-69.

Fox JF. Salt/sediment interaction. Lead Edge. 1998;17(8):1033-41.

Franks SG, Zwingmann $\mathrm{H}$. Origin and timing of late diagenetic illite in the Permian-Carboniferous Unayzah sandstone reservoirs of Saudi Arabia. Am Assoc Pet Geol Bull. 2010;94(8):1133-59.

Goldsmith PJ, Hudson G, van Veen P. Triassic. In: Evans D, Graham C, Armour A, Bathurst P, editors. Millennium atlas: petroleum 
geology central northern North Sea. London: Geological Society of London; 2003. p. 105-27.

Goldsmith PJ, Rich B, Standring J. Triassic correlation and stratigraphy in the South Central Graben, UK North Sea. Geol Soc Lond Spec Publ. 1995;91(1):123-43.

Goldsmith P, Hudson G, Van Veen P. Triassic. The Millenium Atlas: Petroleum geology ofthe central and northern North Sea: Geological Society London, 2003;105-127.

Gowers MBB, Sæbøe A, Saeboe A. On the structural evolution of the Central Trough in the Norwegian and Danish sectors of the North Sea. Mar Pet Geol. 1985;2(4):298-318.

Gradstein FM, Ogg JG, Schmitz MD, Ogg GM, Gradstein FM, All A. The geologic time scale. Hoboken: Elsevier; 2012.

Grant NT, Middleton AJ, Archer S. Porosity trends in the Skagerrak Formation, Central Graben, United Kingdom Continental Shelf: the role of compaction and pore pressure history. Am Assoc Pet Geol Bull. 2014;98(6):1111-43.

Grigsby JD. Origin and growth of authigenic chlorite in sandstones of the Lower Viksburg Formation, South Texas. J Sediment Res. 2001;71(1):27-36.

Hasiotis ST, Van Wagoner JC, Demko TM, Wellner RW, Jones CR, Hill RE, et al. Continental ichnology:using terrestrial and freshwater trace fossils for environmental and climatic interpretations. ContTrace Foss. 2002;51:1-53.

Helgeson DE. Structural development and trap formation in the Central North Sea HP/HY play. Pet Geol Northwest Eur. In: Proceedings of 5th conference petroleum geology of northwest Europe 1999;2:1029-36.

Hillier S, Velde B. Chlorite interstratified with a 7 mineral: and example from offshore Norway and possible implications for the interpretation of the composition of diagenetic chlorites. Clay Miner. 1992;27:475-86.

Hodgson NA, Farnsworth J, Fraser AJ. Salt-related tectonics, sedimentation and hydrocarbon plays in the Central Graben, North Sea, UKCS. Geol Soc Lond Spec Publ. 1992;67(1):31-63.

Houseknecht DW. Assessing the relative importance of compaction processes and cementation to reduction of porosity in sandstones. AAPG Bull. 1987;71(6):633-42.

Houseknecht DW. Intergranular pressure solution in four quartzose sandstones. J Sediment Res. 1988;58(2):228-46.

Hudec MR, Jackson MPA. Terra infirma: understanding salt tectonics. Earth-Sci Rev. 2007;82(1-2):1-28.

Hudec MR, Jackson MPA, Schultz-Ela DD. The paradox of minibasin subsidence into salt: clues to the evolution of crustal basins. Bull Geol Soc Am. 2009;121(1-2):201-21.

Hudec MR, Norton IO, Jackson MPA, Peel FJ. Jurassic evolution of the Gulf of Mexico salt basin. Am Assoc Pet Geol Bull. 2013;97(10):1683-710

Humphreys B, Smith SA, Strong GE. Authigenic chlorite in late Triassic sandstones from the Central Graben, North Sea. Clay Miner. 1989;24:427-44.

Isaksen GH. Central North Sea hydrocarbon systems: generation, migration, entrapment, and thermal degradation of oil and gas. Am Assoc Pet Geol Bull. 2004;88(11):1545-72.

Kape S, Diaz De Souza O, Bushnaq I, Hayes M, Turner I. Predicting production behaviour from deep HPHT Triassic reservoirs and the impact of sedimentary architecture on recovery. Pet Geol From Matur Basins New Front. In: 7th petroleum geology conference 2010;7:405-17.

Lines MD, Auld HA. A petroleum charge model for the Judy and Joanne Fields, Central North Sea: application to exploration and field development. Geol Soc Lond Spec Publ. 2004;237(1):175-206.

Lundegard PD. Sandstone porosity loss; a "big picture" view of the importance of compaction. J Sediment Res. 1992;62(2):250-60.
Mallon AJ, Swarbrick RE. A compaction trend for non-reservoir North Sea Chalk. Mar Pet Geol. 2002;19(5):527-39.

Mallon AJ, Swarbrick RE. Diagenetic characteristics of low permeability, non-reservoir chalks from the Central North Sea. Mar Pet Geol. 2008;25(10):1097-108.

Mandl G, DeJong LNJ, Maltha A. Shear zones in granular material. Rock Mech. 1977;9(2-3):95-144.

Mark G, Rowan MPAJ. Salt-related fault families and fault welds in the northern Gulf of Mexico. Am Assoc Pet Geol Bull. 1999;83(9):1454-84.

Matlack KS, Houseknecht DW, Applin KR. Emplacement of clay into sand by infiltration. J Sediment Pet. 1989;59(1):77-87.

Matthews WJ, Hampson GJ, Trudgill BD, Underhill JR. Controls on fluviolacustrine reservoir distribution and architecture in passive salt-diapir provinces: Insights from outcrop analogs. Am Assoc Pet Geol Bull. 2007;91(10):1367-403.

McKie T. Architecture and behavior of dryland fluvial reservoirs, Triassic Skagerrak Formation, Central North Sea. In: Davidson SK, Leleu S, North CP, editors. From River Rock Rec 2011;97:189-214.

McKie T. Climatic and tectonic controls on Triassic dryland terminal fluvial system architecture, central North Sea. In: Martinius AW, Ravn R, Howell JA, Steel RJ, Wonham JP, editors. From Depos Syst Sediment Successions Nor Cont Margin. International Association of Sedimentologists, Special Publication 46. Chichester: Wiley; 2014;46:19-58.

McKie T, Audretsch P. Depositional and structural controls on Triassic reservoir performance in the Heron Cluster, ETAP, Central North Sea. Pet Geol North-West Eur Glob Perspect. In: Proceedings of 6th petroleum geology conference 2005; p. 285-97.

McKie T, Jolley SJ, Kristensen MB. Stratigraphic and structural compartmentalization of dryland fluvial reservoirs: Triassic Heron Cluster, Central North Sea. Geol Soc Lond Spec Publ. 2010;347(1):165-98.

McKie T, Shannon PM. Comment on "The Permian-Triassic transition and the onset of Mesozoic sedimentation at the northwestern peri Tethyan domain scale: palaeogeographic maps and geodynamic implications" by S. Bourquin, A. Bercovici, J. Lopez-Gomez, J. B. Diez, J. Broutin, A. Palaeogeogr Palaeoclimatol Palaeoecol. 2011;311(1-2):136-43. https://doi.org/10. 1016/j.palaeo.2011.07.016

McKie T, Williams B. Triassic palaeogeography and fluvial dispersal across the northwest European Basins. Geol J. 2009;44(6):711-41.

Moraes MAS, de Ros LF. Infiltrated clays in fluvial Jurassic sandstones of Reconcavo Basin, Northeastern Brazil. J Sediment Res. 1990;60(6):809-19.

Nguyen BTT, Jones SJ, Goulty NR, Middleton AJ, Grant NT, Ferguson A, et al. The role of fluid pressure and diagenetic cements for porosity preservation in Triassic fluvial reservoirs of the Central Graben, North Sea. Am Assoc Pet Geol Bull. 2013;97(8):1273-302.

Oakes CS, Bodnar RJ, Simonson JM. The system $\mathrm{NaClCaCl}_{2} \mathrm{H}_{2} \mathrm{O}$ : I. The ice liquidus at $1 \mathrm{~atm}$ total pressure. Geochim Cosmochim Acta. 1990;54(3):603-10.

Osborne MJ, Swarbrick RE. Mechanisms for generating overpressure in sedimentary basins: a reevaluation. Am Assoc Pet Geol Bull. 1997;81(6):1023-41.

Parsons I, Thompson P, Lee MR, Cayzer N. Alkali feldspar microtextures as provenance indicators in siliciclastic rocks and their role in feldspar dissolution during transport and diagenesis. J Sediment Res. 2005;75:921-42.

Paxton ST, Szabo JO, Ajdukiewicz JM, Klimentidis RE. Construction of an intergranular volume compaction curve for evaluating and 
predicting compaction and porosity loss in rigid-grain sandstone reservoirs. Am Assoc Pet Geol Bull. 2002;86(12):2047-67.

Pittman ED, Larese RE, Heald MT. Clay coats: occurence and relevance to preservation of porosity in sandstones. Orig Diagenes Petrophys Clay Miner Sandstones SEPM Spec. Publ. 1992;47:241-55.

Retallack GJ. Colour guide to paleosols. Chichester: Wiley; 1997.

Sathar S, Jones SJ. Fluid overpressure as a control on sandstone reservoir quality in a mechanical compaction dominated setting: Magnolia Field, Gulf of Mexico. Terra Nova. 2016;28(3):155-62.

Sclater JG, Christie PAF. Continental stretching: an explanation of the post-mid-cretaceous subsidence of the central North Sea. J Geophys Res: Solid Earth (1978-2012). 1980;85(7):3711-39.

Smith RI, Hodgson N, Fulton M. Salt control on Triassic reservoir distribution, UKCS Central North Sea. Pet Geol Northwest Eur. In: Proceedings of 4th conference petroleum geology NW Europe Barbican Centre, London. 1993;547-57.

Stricker S, Jones SJ. Enhanced porosity preservation by pore fluid overpressure and chlorite grain coatings in the Triassic Skagerrak, Central Graben, North Sea, UK. Geol Soc Lond Spec Publ. 2016;435:435.

Stricker S, Jones SJ, Grant NT. Importance of vertical effective stress for reservoir quality in the Skagerrak Formation, Central Graben, North Sea. Mar Pet Geol. 2016a;78:895-909.

Stricker S, Jones SJ, Sathar S, Bowen L, Oxtoby N. Exceptional reservoir quality in HPHT reservoir settings: examples from the Skagerrak Formation of the Heron Cluster, North Sea, UK. Mar Pet Geol. 2016b;77:198-215.
Swarbrick RE. Review of pore-pressure prediction challenges in hightemperature areas. Lead Edge. 2012;31(1):1288-94.

Swarbrick RE, Osborne MJ, Grunberger D, Yardley GS, Macleod G, Aplin AC, et al. Integrated study of the Judy Field (Block 30/7a) — an overpressured Central North Sea oil/gas field. Mar Pet Geol. 2000;17(9):993-1010.

Taylor JCM. Upper Permian-Zechstein. In: Glennie KW, editor. Petroleum geology of the North Sea. 3rd ed. Oxford: Blackwell Science Ltd; 1998. p. 174-211.

Taylor TR, Kittridge MG, Winefield P, Bryndzia LT, Bonnell LM. Reservoir quality and rock properties modeling-Triassic and Jurassic sandstones, greater Shearwater area, UK Central North Sea. Mar Pet Geol. 2015;65:1-21.

Trevena AS, Nash WP. An electron microprobe study of detrital feldspar. SEPM J Sediment Res. 1981;51(1):137-49.

Weibel R. Effects of burial on the clay assemblages in the Triassic Skagerrak Formation, Denmark. Clay Miner. 1999;34(4):619-35.

Wilson MJ, Wilson L, Patey I. The influence of individual clay minerals on formation damage of reservoir sandstones: a critical review with some new insights. Clay Miner. 2014;49(2):147-64.

Winefield P, Gilham R, Elsinger R. Plumbing the depths of the Central Graben: towards an integrated pressure, fluid and charge model for the Central North Sea HPHT play. Pet Geol Conf Ser. 2005;6:1301-15.

Worden RH, Morad S. Clay minerals in sandstones: controls on formation, distribution and evolution. Clay, minerals, cement, sandstones. Oxford: Blackwell Publishing Ltd.; 2003. p. 1-41. 